\title{
Structuur en toekomstige ontwikkelingen op de arbeidsmarkt voor technici in de chemie en de metaal
}

Citation for published version (APA):

Borghans, L., \& Willems, E. J. T. A. (1994). Structuur en toekomstige ontwikkelingen op de arbeidsmarkt voor technici in de chemie en de metaal. Researchcentrum voor Onderwijs en Arbeidsmarkt, Faculteit der Economische Wetenschappen. ROA Working Papers No. 2 https://doi.org/10.26481/umarow.1994002

Document status and date:

Published: 01/01/1994

DOI:

10.26481/umarow.1994002

Document Version:

Publisher's PDF, also known as Version of record

\section{Please check the document version of this publication:}

- A submitted manuscript is the version of the article upon submission and before peer-review. There can be important differences between the submitted version and the official published version of record.

People interested in the research are advised to contact the author for the final version of the publication, or visit the DOI to the publisher's website.

- The final author version and the galley proof are versions of the publication after peer review.

- The final published version features the final layout of the paper including the volume, issue and page numbers.

Link to publication

\footnotetext{
General rights rights.

- You may freely distribute the URL identifying the publication in the public portal. please follow below link for the End User Agreement:

www.umlib.nl/taverne-license

Take down policy

If you believe that this document breaches copyright please contact us at:

repository@maastrichtuniversity.nl

providing details and we will investigate your claim.
}

Copyright and moral rights for the publications made accessible in the public portal are retained by the authors and/or other copyright owners and it is a condition of accessing publications that users recognise and abide by the legal requirements associated with these

- Users may download and print one copy of any publication from the public portal for the purpose of private study or research.

- You may not further distribute the material or use it for any profit-making activity or commercial gain

If the publication is distributed under the terms of Article $25 \mathrm{fa}$ of the Dutch Copyright Act, indicated by the "Taverne" license above, 


\section{STRUCTUUR EN TOEKOMSTIGE ONTWIKKELINGEN OP DE ARBEIDSMARKT VOOR TECHNICI \\ IN DE CHEMIE EN DE METAAL}

ROA-W-1994/2

L. Borghans en E.J.T.A. Willems

RESEARCHCENTRUM VOOR ONDERWIJS EN ARBEIDSMARKT

Faculteit der Economische Wetenschappen

Rijksuniversiteit Limburg

Maastricht, april 1994 


\section{CIP-GEGEVENS KONINKLIJKE BIBLIOTHEEK, DEN HAAG}

\section{Borghans, L.}

Structuur en toekomstige ontwikkelingen op de arbeidsmarkt voor technici in de chemie en de metaal / L. Borghans en E.J.T.A. Willems. - Maastricht : Researchcentrum voor Onderwijs en Arbeidsmarkt, Faculteit der Economische Wetenschappen, Rijksuniversiteit Limburg. ([Werkdocument] / Researchcentrum voor Onderwijs en Arbeidsmarkt, ISSN 0922-4645; ROAW-1994/2)

Met lit. opg.

ISBN 90-5321-127-6

Trefw.: arbeidsmarkt ; technici / onderwijs en arbeidsmarkt ; Nederland. 
INHOUDSOPGAVE

Bladzijde

VOORWOORD

$\begin{array}{ll}\text { 1. INLEIDING } & 1\end{array}$

2. SECTORSTRUCTUUR 3

3. BEROEPENSTRUCTUUR PER SECTOR

$\begin{array}{ll}\text { 4. OPLEIDINGENSTRUCTUUR PER BEROEP } & 18\end{array}$

5. CONFRONTATIE VRAAG-AANBOD 25

$\begin{array}{lll}\text { 6. BESLUIT } & 30\end{array}$

LITERATUUR 32

BIJLAGE A. VERWACHTE WERKGELEGENHEIDSONTWIKKELING NAAR SECTOR EN BEROEP, OPGESPLITST NAAR SECTOREFFECT EN BEROEPSEFFECT 



\section{VOORWOORD}

In dit werkdocument, dat is opgesteld in opdracht van de directie Algemeen Technologiebeleid van het Ministerie van Economische Zaken, wordt een beeld geschetst van de verwachte ontwikkelingen op de arbeidsmarkt voor technici. Daarbij staat een tweetal bedrijfssectoren, te weten de chemie en de metaal, elektrotechnische en transportmiddelenindustrie centraal.

De gegevens in dit werkdocument zijn ontleend aan het Informatiesysteem OnderwijsArbeidsmarkt dat door het Researchcentrum voor Onderwijs en Arbeidsmarkt (ROA) is ontwikkeld. Het informatiesysteem wordt gefinancierd door het Ministerie van Onderwijs en Wetenschappen, het Centraal Bestuur voor de Arbeidsvoorziening (CBA) en het Landelijk Dienstverlenend Centrum voor Studie- en Beroepskeuzevoorlichting (LDC). De hier gepresenteerde gegevens zijn deels eerder gepubliceerd in het ROA-rapport De arbeidsmarkt naar opleiding en beroep tot 1998 of de bijbehorende Statistische bijlage. Anders dan in dat rapport wordt hier dieper ingegaan op de verwachte verschuivingen in de beroepen- en opleidingenstructuur. Met name wordt nagegaan of de werkgelegenheidsontwikkeling van een bepaald beroep vooral samenhangt met de sectorale ontwikkelingen of dat er sprake is van verschuivingen van de beroepenstructuur binnen bedrijfssectoren. Evenzo wordt de werkgelegenheidsontwikkeling per opleiding binnen de onderscheiden technische beroepen belicht. 



\section{INLEIDING}

Voldoende aanbod van adequaat technisch geschoold personeel wordt door velen gezien als een belangrijke randvoorwaarde voor een hoge kennisintensieve economische groei. Voor het Ministerie van Economische Zaken is het trachten te bewerkstelligen van een gunstige kennisinfrastructuur voor het realiseren van een dergelijke groei één van de centrale invalshoeken voor het beleid. Het is bij deze beleidsontwikkeling van belang om een zo gedetailleerd en nauwkeurig mogelijk beeld te krijgen van de werkgelegenheidsstructuur voor technisch opgeleiden en de te verwachten ontwikkelingen daarin.

Door het ROA is het Informatiesysteem Onderwijs-Arbeidsmarkt ontwikkeld, dat voor een deel in deze informatiebehoefte voorziet. Dit informatiesysteem bevat gegevens over 93 beroepsklassen en 49 opleidingstypen, verdeeld over de volle breedte van de arbeidsmarkt. De informatie kan daarbij in drie delen worden onderverdeeld:

- actuele data en trends in het recente verleden;

- risico-indicatoren;

- middellange-termijn-prognoses.

De nieuwste versie van het informatiesysteem is onlangs verschenen (zie ROA, 1993a en 1993b).

Bij de arbeidsmarktprognoses voor technisch opgeleiden wordt in het ROA-informatiesysteem een onderscheid gemaakt tussen zeven opleidingstypen:

- VBO technisch;

- MBO technisch laboratorium;

- MBO technisch;

- HBO technisch laboratorium;

- HBO technisch;

- WO wis- en natuurkunde;

- WO technisch.

Onlangs is echter nagegaan of het mogelijk is om de arbeidsmarktgegevens en -prognoses op een meer gedetailleerd niveau samen te stellen (zie Willems, 1993). De conclusie van dat onderzoek is dat een verdere verbijzondering inderdaad mogelijk is. Inmiddels is gestart met de uitvoering van een project waarbij de meest recente prognoses van het informatiesysteem bij bepaalde opleidingstypen worden verbijzonderd. De eerste resultaten zullen naar verwachting in het najaar van 1994 worden gepubliceerd.

Het doel van dit werkdocument is het verkrijgen van een beter inzicht in de werkgelegenheidsstructuur voor technische beroepsbeoefenaren en/of technisch opgeleiden. Ook de verwachte toekomstige ontwikkelingen daarin zullen worden belicht. Deze laatste gegevens zullen zijn gebaseerd op de werkgelegenheidsmodellen die zijn opgesteld voor de meest recente versie van het ROA-informatiesysteem. In dit werkdocument zal de nadruk worden gelegd op de ontwikkelingen voor de technici in een tweetal bedrijfssectoren, te weten de chemie en de metaal, elektrotechnische en transportmiddelenindustrie. 
De verdere opbouw van dit werkdocument is als volgt. In paragraaf 2 wordt ingegaan op de huidige sectorstructuur van de werkgelegenheid en de verwachte ontwikkelingen daarin tot 1998. Paragraaf 3 en 4 gaan respectievelijk in op de beroepenstructuur per sector en de opleidingenstructuur per beroep. Ook hier komen de verwachte ontwikkelingen tot 1998 aan de orde. In paragraaf 5 wordt vervolgens de vraag-aanbod-confrontatie voor technisch opgeleiden weergegeven, zoals die in het ROA-informatiesysteem is opgesteld, voorafgegaan door een overzicht van de verwachte vervangingsvraag en de verwachte instroom van schoolverlaters ${ }^{1}$.

1. Zie voor een toelichting op de opbouw van het prognosemodel van het informatiesysteem onderwijsarbeidsmarkt Dekker, De Grip, Borghans, Matheeuwsen, Wieling en Willems (1993). 


\section{SECTORSTRUCTUUR}

In Nederland zijn er in totaal ruim 5,8 miljoen mensen voor tenminste 12 uur per week werkzaam ${ }^{2}$. De chemische sector is, zoals tabel 2.1 laat zien, op basis van de Athena-indeling van het Centraal Planbureau (CPB), één van de kleinere sectoren van ons land. In totaal werken er ongeveer 140.000 personen in deze sector, hetgeen overeenkomt met ruim $2 \%$ van de totale werkgelegenheid. De metaal, elektrotechnische en transportmiddelenindustrie ${ }^{3}$ maakt ongeveer $9 \%$ van de totale Nederlandse werkgelegenheid uit. In 1992 zijn er ruim 500.000 arbeidskrachten in deze sector werkzaam.

Tabel 2.1. Aantal werkenden per bedrijfstak 1992

Bedrijfstak

aantal

werkenden

Landbouw, visserij en bosbouw

237.000

Voedings- en genotmiddelenindustrie

166.000

Chemie

139.000

Metaal, elektrotechnische en transportmiddelenindustrie

524.000

Overige industrie

255.000

Energie

64.000

Bouw

415.000

Handel

823.000

Vervoer en communicatie

373.000

Overige commerciële dienstverlening

961.000

Kwartaire diensten

923.000

Openbaar bestuur, politie, defensie en onderwijs

848.000

Totaal (incl. bedrijfstak onbekend)

5.844 .000

Bron: CBS/ROA

Verder blijkt uit de tabel dat een groot deel van de werkgelegenheid in ons land is geconcentreerd in de commerciële en niet-commerciële dienstverlening. Samen vertegenwoordigen de dienstensectoren (met inbegrip van de sector bouw) ongeveer drie kwart van de totale werkgelegenheid. De sector 'Overige commerciële dienstverlening' is daarbij met bijna 1 miljoen werkenden het grootst. In elk van de sectoren 'Handel', 'Kwartaire diensten' en 'Openbaar bestuur, politie, defensie en onderwijs' zijn echter ook meer dan 800.000 mensen werkzaam.

Tabel 2.2 geeft vervolgens een overzicht van de verwachte ontwikkelingen in de werkgelegenheid voor de onderscheiden bedrijfssectoren in de periode tot 1998 . Deze cijfers

2. Deze restrictie van tenminste 12 uur per week is overeenkomstig de nieuwe definitie van de beroepsbevolking (zie CBS, 1993).

3. In de Athena-indeling worden deze drie sectoren niet apart onderscheiden. In het vervolg van dit werkdocument zullen deze sectoren worden aangeduid met de verzamelterm metalektro. 
zijn gebaseerd op het Centraal Economisch Plan 1993 van het CPB (1993) en omgerekend van arbeidsvolume naar werkzame personen. $\mathrm{Er}$ is uitgegaan van het door het $\mathrm{CPB}$ onderscheiden behoedzame scenario. In dit scenario wordt een bescheiden groei van de werkgelegenheid verwacht van ongeveer $0,7 \%$ gemiddeld per jaar. In de tabel is tevens aangegeven hoe de sectoren zich de afgelopen jaren hebben ontwikkeld. Het blijkt dat er in de periode 1988-1992 nog sprake was van een werkgelegenheidsgroei van ruim $1,5 \%$ per jaar.

Tabel 2.2. Ontwikkeling van het aantal werkenden per bedrijfstak 1988-1992 en verwachte ontwikkeling 1993-1998 (gemiddelde jaarlijkse groei)

\begin{tabular}{lcc}
\hline Bedrijfstak & $1988-1992$ & $1993-1998$ \\
& $\%$ \\
& $\%$ & $-0,5$ \\
Landbouw, visserij en bosbouw & $-1,6$ & 1,4 \\
Voedings- en genotmiddelenindustrie & 0,9 & $-0,2$ \\
Chemie & 1,0 & $-0,1$ \\
Metaal, elektrotechnische en transportmiddelenindustrie & 1,4 & 0,2 \\
Overige industrie & 1,0 & 0,7 \\
Energie & $-1,5$ & 1,0 \\
Bouw & $-0,3$ & 0,7 \\
Handel & 1,8 & 1,2 \\
Vervoer en communicatie & 2,3 & 1,9 \\
Overige commerciële dienstverlening & 3,7 & $-0,4$ \\
Kwartaire diensten & 2,0 & 0,7 \\
Openbaar bestuur, politie, defensie en onderwijs & $-0,5$ & 1,5 \\
Totaal (incl. bedrijfstak onbekend) & & \\
\hline
\end{tabular}

\section{Bron: $\mathrm{CBS} / \mathrm{CPB} / \mathrm{ROA}$}

De chemie vormt ten aanzien van de toekomstige werkgelegenheidsontwikkeling duidelijk een positieve uitschieter. Naar verwachting groeit in deze sector de werkgelegenheid in de periode 1993-1998 met gemiddeld 1,4\% per jaar. Daarmee is de chemie de enige industriële sector, waarvoor een werkgelegenheidsgroei wordt verwacht. In de metalektro zal de werkgelegenheid de komende jaren licht afnemen. De verwachte werkgelegenheidskrimp bedraagt hier $0,2 \%$ per jaar. In het eind van de jaren ' 80 en het begin van de jaren '90 was er voor de industriële sectoren nog sprake van een lichte groei van de werkgelegenheid, ofschoon deze stijging geringer was dan in de meeste andere sectoren. De metalektro is in die afgelopen periode van de industriële sectoren de sterkst groeiende sector geweest.

De tabel laat verder zien dat de dienstensectoren naar verwachting ook de komende jaren zullen blijven groeien. Vooral in de kwartaire dienstverlening is er sprake van een aanzienlijke werkgelegenheidsgroei van bijna $2 \%$ gemiddeld per jaar. Voor de andere dienstensectoren wordt een toename van de werkgelegenheid van circa $1 \%$ per jaar verwacht. Daarmee is de groei overigens fors lager dan in de afgelopen jaren. Voor de sector 'Openbaar bestuur, politie, defensie en onderwijs' wordt de daling van de werkgelegenheid, die zich de afgelopen periode heeft voorgedaan, voortgezet. 


\section{BEROEPENSTRUCTUUR PER SECTOR}

Naast de ontwikkeling van de werkgelegenheid in een sector als geheel is, om een beeld te krijgen van de werkgelegenheidsontwikkeling voor technici, de ontwikkeling binnen een sector van belang. Het gaat dan vooral om de ontwikkeling van de beroepenstructuur binnen de onderscheiden bedrijfssectoren. In deze paragraaf zal worden ingegaan op de werkgelegenheid naar beroepssegment voor de technische, ambachts- en industrieberoepen ${ }^{4}$. Ook wordt aangegeven hoe deze technische beroepen in de sectoren chemie en metalektro zijn vertegenwoordigd. Vervolgens zal worden ingegaan op de verwachte werkgelegenheidsontwikkeling in de onderscheiden beroepssegmenten. Daarbij wordt deze ontwikkeling tevens afgezet tegen de werkgelegenheidsontwikkeling per sector. Aan het slot van deze paragraaf wordt voor elk van de onderscheiden beroepssegmenten een beroepenfiche opgesteld, waarin een kort beeld wordt geschetst van de belangrijkste bedrijfssectoren voor het desbetreffende beroepssegment en wordt aangegeven in welke sectoren zich de grootste werkgelegenheidsgroei of -krimp voor dat beroep voordoet.

\section{Beroepenstructuur}

Tabel 3.1. Aantal werkenden per beroepssegment 1992

\begin{tabular}{ll} 
ROA- beroepssegment & aantal \\
code & werkenden \\
\hline
\end{tabular}

$301 \quad$ Lagere technische, ambachts- en industrieberoepen

302 Middelbare technische, ambachts- en industrieberoepen

400.000

Hogere technische, ambachts- en industrieberoepen

41.000

303

Lagere voedings- en genotmiddelenberoepen

67.000

Lagere textielberoepen

49.000

321

Lagere hout- en papierberoepen

129.000

Lagere grafische beroepen

54.000

Lagere chemische beroepen

28.000

351

361

Lagere metaalberoepen

262.000

Middelbare metaalberoepen

62.000

Hogere metaalberoepen

12.000

Lagere elektrotechnische beroepen

26.000

Middelbare elektrotechnische beroepen

114.000

Hogere elektrotechnische beroepen

11.000

Lagere bouwmaterialen-, glas- en aardewerkberoepen

37.000

Lagere bouw- en installatieberoepen

369.000

Middelbare bouw- en installatieberoepen

30.000

392

Hogere bouw- en installatieberoepen

28.000

Totaal technische, ambachts- en industrieberoepen

1.772 .000

Bron: CBS/ROA

4. Gebaseerd op de ROA-beroepenclassificatie 1990. Zie voor een verdere toelichting op deze classificatie Van de Loo, Dekker en De Grip (1992). 
In tabel 3.1 wordt een overzicht gegeven van het aantal werkenden per ROA-beroepssegment. Bij deze beroepssegmenten is op basis van de opleidingsachtergrond van de werkenden een onderverdeling gemaakt naar richting (bv. elektrotechnisch, bouw- en installatie) en naar niveau. De naamgeving van de beroepssegmenten is gebaseerd op de bedrijfssectoren waarin men doorgaans werkzaam is. De tabel laat zien dat in totaal bijna 1,8 miljoen werkenden een technisch beroep hebben. Dit betekent dat ongeveer een derde van alle arbeidskrachten in de technische richting werkzaam is. Van hen heeft ruim $60 \%$ een lager technisch beroep, ongeveer $35 \%$ een middelbaar technisch beroep, terwijl circa $5 \%$ een technisch beroep op hoger niveau uitoefent.

De technische, ambachts- en industrieberoepen (code 301-303) buiten beschouwing latend ${ }^{5}$, blijkt de grootste technische beroepsrichting de richting bouw- en installatie te zijn. Ruim 400.000 arbeidskrachten oefenen een beroep in deze richting uit. Ook de richtingen metaal en elektrotechniek zijn met respectievelijk ruim 300.000 en ongeveer 150.000 werkenden vrij groot. De chemische richting, waarin op grond van de ROA-beroepenclassificatie alleen de lagere chemische beroepen zijn vertegenwoordigd ${ }^{6}$, kent slechts 28.000 werkenden.

\section{Beroepenstructuur per sector}

Zoals reeds is vermeld in de inleiding, staan in dit werkdocument vooral de sectoren chemie en metalektro centraal. In tabel 3.2 staat aangegeven hoe de onderscheiden technische beroepen in deze beide sectoren zijn vertegenwoordigd. Daarbij moet worden opgemerkt dat alleen gegevens beschikbaar zijn voor de 'cellen' met tenminste 5.000 werkenden, vanwege de publikatierestricties die het Centraal Bureau voor de Statistiek (CBS) stelt ten aanzien van de Enquête Beroepsbevolking (EBB).

In de sector chemie is het beroepssegment 'Middelbare technische ambachts- en industrieberoepen' met 26.000 werkenden het grootst. Circa $7 \%$ van alle werkenden met dit beroep is in de chemische sector werkzaam. Niet verrassend is dat het merendeel van degenen met een lager chemisch beroep in deze sector werkzaam zijn. Van de 28.000 lagere chemische beroepsbeoefenaren werken er 18.000 in de chemie. Verder blijkt dat het beroepssegment 'Lagere bouwmaterialen-, glas- en aardewerkberoepen' met een werkgelegenheidsaandeel van $30 \%$, sterk in de chemische sector is vertegenwoordigd?

5. Deze beroepen zouden kunnen worden beschouwd als een 'overig-categorie'. De 'Lagere technische, ambachts- en industrieberoepen' bestaan onder meer uit machinisten. Bij de 'Middelbare technische, ambachts- en industrieberoepen' zijn de leidinggevenden in de produktie de belangrijkste categorie. Het beroepssegment 'Hogere technische ambachts- en industrieberoepen' bevat de technische specialisten, zoals wis-, natuur- en scheikundigen, biologen e.d.

6. De hogere chemische beroepen zijn, zoals reeds is aangegeven, ondergebracht bij de 'Hogere technische, ambachts- en industrieberoepen'.

7. Waarschijnlijk hangt dit samen met het feit dat de CBS-beroepsgroepen 'Rubber-, plasticproduktenmakers (excl. buitenbanden)' en 'Buitenbandenbouwers, vulcaniseerders e.d.' tot dit beroepssegment worden gerekend. 
Tabel 3.2. Aantal en percentage werkenden per beroepssegment in de sectoren chemie en metalektro 1992

\begin{tabular}{|c|c|c|c|c|c|}
\hline \multirow{2}{*}{$\begin{array}{l}\text { ROA- } \\
\text { code }\end{array}$} & \multirow[t]{2}{*}{ beroepssegment } & \multicolumn{2}{|c|}{ chemie } & \multicolumn{2}{|c|}{ metalektro } \\
\hline & & aantal & $\%$ & aantal & $\%$ \\
\hline 301 & Lagere technische, ambachts- en industrieberoepen & - & - & 6.000 & 11 \\
\hline 302 & Middelbare technische, ambachts- en industrieberoepen & 26.000 & 7 & 68.000 & 17 \\
\hline 303 & Hogere technische, ambachts- en industrieberoepen & 6.000 & 15 & - & - \\
\hline 311 & Lagere voedings- en genotmiddelenberoepen & - & - & - & - \\
\hline 321 & Lagere textielberoepen & - & - & - & - \\
\hline 331 & Lagere hout- en papierberoepen & - & - & 10.000 & 8 \\
\hline 341 & Lagere grafische beroepen & - & - & 5.000 & 9 \\
\hline 351 & Lagere chemische beroepen & 18.000 & 64 & - & - \\
\hline 361 & Lagere metaalberoepen & 9.000 & 3 & 164.000 & 62 \\
\hline 362 & Middelbare metaalberoepen & - & - & 7.000 & 11 \\
\hline 363 & Hogere metaalberoepen & - & - & 5.000 & 42 \\
\hline 371 & Lagere elektrotechnische beroepen & - & - & 15.000 & 58 \\
\hline 372 & Middelbare elektrotechnische beroepen & - & - & 30.000 & 26 \\
\hline 373 & Hogere elektrotechnische beroepen & - & - & 5.000 & 45 \\
\hline 381 & Lagere bouwmaterialen-, glas- en aardewerkberoepen & 11.000 & 30 & 8.000 & 22 \\
\hline 391 & Lagere bouw- en installatieberoepen & - & - & 28.000 & 8 \\
\hline 392 & Middelbare bouw- en installatieberoepen & - & - & - & - \\
\hline 393 & Hogere bouw- en installatieberoepen & - & - & - & - \\
\hline \multicolumn{6}{|c|}{$-=$ minder dan 5.000 werkenden } \\
\hline
\end{tabular}

Bron: CBS/ROA

Het beroepssegment 'Lagere metaalberoepen' is in de metalektro verreweg het grootst. Ruim 160.000 werkenden met het desbetreffende beroep zijn in deze sector werkzaam. Dit komt overeen met $62 \%$. Ook de 'Lagere elektrotechnische beroepen' en de 'Hogere elektrotechnische beroepen' zijn sterk in de metalektro vertegenwoordigd. Het werkgelegenheidsaandeel van de sector bedraagt voor beide beroepssegmenten respectievelijk $58 \%$ en $45 \%$. Ook van degenen die een hoger metaalberoep of een middelbaar elektrotechnisch beroep uitoefenen zijn er relatief veel in deze sector werkzaam.

Naast de genoemde voor-de-hand-liggende beroepen zijn nog enkele andere beroepssegmenten in de technische richting sterk in de metalektro vertegenwoordigd. Vergeleken met het totale werkgelegenheidsaandeel van deze sector van $9 \%$, zijn er vooral ook veel werkenden in de beroepssegmenten 'Lagere bouwmaterialen-, glas- en aardewerkberoepen' en de 'Middelbare technische, ambachts- en industrieberoepen'. Het werkgelegenheidsaandeel van de metalektro bedraagt voor deze beroepen respectievelijk $22 \%$ en $17 \%$.

\section{Verwachte ontwikkeling in de beroepenstructuur per sector}

Met behulp van het door het ROA ontwikkelde beroepenmodel (zie Borghans en Heijke, 1994) kunnen de verwachte ontwikkelingen in de sectorstructuur worden verbijzonderd naar de 
verschillende beroepen. In dit model worden de veranderingen in de beroepenstructuur gerelateerd aan een trend en enkele verklarende variabelen. Hierdoor wordt er rekening mee gehouden dat de werkgelegenheidsontwikkeling van verschillende beroepen, anders kan reageren op bepaalde conjuncturele omstandigheden. De verwachte werkgelegenheidsgroei van de onderscheiden beroepssegmenten in de periode 1993-1998 is weergegeven in tabel 3.3. Tevens is in de tabel aangegeven hoe de desbetreffende beroepen zich naar verwachting in de chemie en de metalektro zullen ontwikkelen.

Tabel 3.3. Verwachte ontwikkeling van het aantal werkenden per beroepssegment in de sectoren chemie en metalektro en totaal van alle bedrijfssectoren 1993-1998 (gemiddelde jaarlijkse groei) ten opzichte van de werkgelegenheid van het beroep in de sector

\begin{tabular}{|c|c|c|c|c|}
\hline $\begin{array}{l}\text { ROA- } \\
\text { code }\end{array}$ & beroepssegment & $\begin{array}{l}\text { chemie } \\
\%\end{array}$ & $\begin{array}{c}\text { metalektro } \\
\%\end{array}$ & $\begin{array}{c}\text { totaal } \\
\%\end{array}$ \\
\hline 301 & Lagere technische, ambachts- en industrieberoepen & - & $-2,6$ & 1,0 \\
\hline 302 & Middelbare technische, ambachts- en industrieberoepen & 3,0 & $-0,4$ & 1,5 \\
\hline 303 & Hogere technische, ambachts- en industrieberoepen & 2,6 & - & 1,8 \\
\hline 311 & Lagere voedings- en genotmiddelenberoepen & - & - & $-0,9$ \\
\hline 321 & Lagere textielberoepen & - & - & $-2,6$ \\
\hline 331 & Lagere hout- en papierberoepen & - & $-0,5$ & $-0,2$ \\
\hline 341 & Lagere grafische beroepen & - & $-0,0$ & 1,8 \\
\hline 351 & Lagere chemische beroepen & $-0,8$ & - & $-0,2$ \\
\hline 361 & Lagere metaalberoepen & 8,0 & $-1,2$ & $-0,1$ \\
\hline 362 & Middelbare metaalberoepen & - & $-2,5$ & 0,0 \\
\hline 363 & Hogere metaalberoepen & - & 1,6 & 0,7 \\
\hline 371 & Lagere elektrotechnische beroepen & - & $-1,5$ & $-1,2$ \\
\hline 372 & Middelbare elektrotechnische beroepen & - & $-0,1$ & 0,1 \\
\hline 373 & Hogere elektrotechnische beroepen & - & 4,3 & 2,0 \\
\hline 381 & Lagere bouwmaterialen-, glas- en aardewerkberoepen & $-4,8$ & 2,6 & $-2,4$ \\
\hline 391 & Lagere bouw- en installatieberoepen & - & $-0,3$ & 0,5 \\
\hline 392 & Middelbare bouw- en installatieberoepen & - & - & 0,1 \\
\hline 393 & Hogere bouw - en installatieberoepen & - & - & 1,9 \\
\hline
\end{tabular}

Bron: ROA

Het vrij kleine beroepssegment 'Hogere elektrotechnische beroepen' maakt van de technische beroepen naar verwachting de komende jaren de relatief grootste groei door. De groei bedraagt hier gemiddeld $2 \%$ per jaar. In de metalektro is er echter sprake van de nog grotere groei van dit beroep, namelijk ruim $4 \%$ per jaar. Verder komen ook de 'Hogere technische, ambachts- en industrieberoepen', de 'Lagere grafische beroepen' en de 'Hogere bouw- en installatieberoepen' naar voren als de beroepssegmenten met de grootste groeipercentages. Daarentegen zal voor de 'Lagere textielberoepen' en de 'Lagere bouwmaterialen-, glas- en aardewerkberoepen' de werkgelegenheid fors afnemen. De werkgelegenheidsdaling bedraagt hier naar verwachting zelfs meer dan $2 \%$ per jaar. Voor het laatstgenoemde beroep is het daarbij opmerkelijk dat in de sector metalektro een groei van circa $2 \frac{1}{2} \%$ optreedt, terwijl er in de chemische sector naar verwachting sprake zal zijn van een afname van de werkgelegenheid van maar liefst bijna $5 \%$. 
Als naar het verwachte beeld per sector wordt gekeken, dan maakt in de sector chemie opvallend genoeg het beroepssegment 'Lagere metaalberoepen' de grootste groei door. Ook de middelbare en de hogere technische, ambachts- en industrieberoepen kennen in deze sector een redelijke groei van respectievelijk $2,6 \%$ en $3 \%$. Zoals hierboven reeds is opgemerkt, wordt voor de 'Lagere bouwmaterialen-, glas- en aardewerkberoepen' een aanzienlijke werkgelegenheidsdaling in deze sector verwacht. Het desbetreffende beroep is daarmee de sterkste daler binnen de chemische sector.

In de metalektro zijn de 'Hogere elektrotechnische beroepen' de sterkste groeiers. Ook voor de 'Lagere bouwmaterialen-, glas- en aardewerkberoepen' wordt, zoals reeds is aangegeven, in deze sector een redelijk grote werkgelegenheidsgroei verwacht. Voor de meeste beroepen in de metalektro is de werkgelegenheidsontwikkeling overeenkomstig het algehele beeld voor deze sector: een lichte daling van het aantal werkenden.

Zoals reeds eerder is aangegeven, is bij de meest recente ROA-prognoses naar opleiding en beroep uitgegaan van het door het CPB onderscheiden behoedzame scenario. Bij een op middellange termijn sterker aantrekkende economie, zou ook de werkgelegenheid voor technici (verder) kunnen toenemen. Op grond van een uitgevoerde beperkte 'gevoeligheidsanalyse' kan worden geconcludeerd dat binnen de chemische industrie een uitbreiding van de produktiecapaciteit en van de totale werkgelegenheid meer dan evenredig zal leiden tot extra banen voor technische beroepsbeoefenaren. Een werkgelegenheidsimpuls voor de metalektro houdt in dat de werkgelegenheid voor technici en de werkgelegenheid voor niet-technici binnen deze sector in min of meer gelijke mate zal toenemen.

Bij de hierboven genoemde groeiverwachtingen per sector kan een onderscheid worden gemaakt in een sectoreffect en een beroepseffect. Het sectoreffect geeft aan welk deel van de werkgelegenheidsgroei van het beroep in een bedrijfssector louter tot stand komt als gevolg van de ontwikkeling van de werkgelegenheid in de desbetreffende bedrijfssector. Het beroepseffect geeft daarnaast de additionele groei weer als gevolg van veranderingen in de beroepenstructuur ${ }^{8}$ binnen de bedrijfssector. Het onderscheid tussen sectoreffect en beroepseffect kan worden geillustreerd aan de hand van een eenvoudig voorbeeld.

Schema 3.1. Sectoreffect en beroepseffect: werkgelegenheid jaar $t$ en jaar $t+1$ (getallenvoorbeeld)

\begin{tabular}{|c|c|c|c|c|}
\hline & \multicolumn{2}{|c|}{$\begin{array}{l}\text { Werkgelegenheid jaar } \mathrm{t} \\
\text { sector } 1 \\
\text { sector } 2\end{array}$} & \multicolumn{2}{|c|}{ Werkgelegenheid jaar $t+1$} \\
\hline Beroep 1 & 10 & 90 & 20 & 125 \\
\hline Beroep 2 & 40 & 60 & 40 & 40 \\
\hline Totaal & 50 & 150 & 60 & 165 \\
\hline
\end{tabular}

8. Formeel is er ook nog sprake van een zeer klein interaktie-effect. Dit wordt hier niet expliciet in beeld gebracht, maar wordt tot het beroepseffect gerekend. 
In schema 3.1 staat de werkgelegenheid voor twee beroepen in twee sectoren weergegeven. In dit voorbeeld is de werkgelegenheid in sector 1 met 10 personen gestegen en in sector 2 met 15 personen. Dit komt overeen met respectievelijk $20 \%$ en $10 \%$. Het sectoreffect geeft aan wat de groei van het beroep zou zijn geweest bij onveranderde beroepenstructuur, dat wil zeggen als ieder beroep binnen de sector met eenzelfde percentage zou groeien. Met het beroepseffect wordt vervolgens de verschuiving in de beroepenstructuur weergegeven, waarbij een groei van een beroep in een bepaalde sector wordt gecompenseerd door de krimp van een ander beroep in de desbetreffende sector. Het beroepseffect is daardoor totaal gezien per sector per definitie gelijk aan 0 . Te zamen vormen sectoreffect en beroepseffect het totale werkgelegenheidseffect van een beroep in een bedrijfssector. Schema 3.2 geeft aan hoe groot het sectoreffect, het beroepseffect en het totaal effect voor de beroepen en sectoren in dit voorbeeld is. De schema's 3.3 en $\mathbf{3 . 4}$ geven deze effecten eveneens, maar dan respectievelijk gerelateerd aan de werkgelegenheid van het beroep in de desbetreffende sector en aan de totale werkgelegenheid van het beroep.

Schema 3.2. Sectoreffect en beroepseffect: aantallen (getallenvoorbeeld)

\begin{tabular}{|c|c|c|c|c|c|c|}
\hline & \multicolumn{2}{|c|}{ sectoreffect } & \multicolumn{2}{|c|}{ beroepseffect } & \multicolumn{2}{|c|}{ totaal effect } \\
\hline & sector 1 & sector 2 & sector 1 & sector 2 & sector 1 & sector 2 \\
\hline Beroep 1 & 2 & 9 & 8 & 26 & 10 & 35 \\
\hline Beroep 2 & 8 & 6 & -8 & -26 & 0 & -20 \\
\hline Totaal & 10 & 15 & 0 & 0 & 10 & 15 \\
\hline
\end{tabular}

Schema 3.3. Sectoreffect en beroepseffect ten opzichte van de werkgelegenheid van het beroep in de sector (getallenvoorbeeld)

\begin{tabular}{lcccccc}
\hline & \multicolumn{2}{c}{ sectoreffect } & \multicolumn{2}{c}{ beroepseffect } \\
& $\begin{array}{c}\text { sector } 1 \\
\%\end{array}$ & $\begin{array}{c}\text { sector } 2 \\
\%\end{array}$ & $\begin{array}{c}\text { sector } 1 \\
\%\end{array}$ & $\begin{array}{c}\text { totaal effect } \\
\text { sector } 2\end{array}$ & $\begin{array}{c}\text { sector } 1 \\
\%\end{array}$ & $\begin{array}{c}\text { sector } 2 \\
\%\end{array}$ \\
\hline Beroep 1 & 20 & 10 & 80 & 28,9 & 100 & 38,9 \\
Beroep 2 & 20 & 10 & -20 & $-43,3$ & 0 & $-33,3$ \\
Totaal & 20 & 10 & 0 & 0 & 20 & 10 \\
\hline
\end{tabular}

Schema 3.4. Sectoreffect en beroepseffect ten opzichte van de totale werkgelegenheid van het beroep (getallenvoorbeeld)

\begin{tabular}{lcccccc}
\hline & \multicolumn{2}{c}{ sectoreffect } & \multicolumn{2}{c}{ beroepseffect } & \multicolumn{2}{c}{ totaal effect } \\
& $\begin{array}{c}\text { sector 1 } \\
\%\end{array}$ & $\begin{array}{c}\text { sector } 2 \\
\%\end{array}$ & $\begin{array}{c}\text { sector } 1 \\
\%\end{array}$ & $\begin{array}{c}\text { sector } 2 \\
\%\end{array}$ & $\begin{array}{c}\text { sector 1 } \\
\%\end{array}$ & $\begin{array}{c}\text { sector 2 } \\
\%\end{array}$ \\
\hline Beroep 1 & 2 & 9 & 8 & 26 & 10 & 35 \\
Beroep 2 & 8 & 6 & -8 & -26 & 0 & -20 \\
\hline
\end{tabular}


De hierboven in tabel 3.3 vermelde percentages over de verwachte ontwikkeling van de technische beroepen in de sectoren chemie en metalektro betreffen in feite het totaal effect ten opzichte van de werkgelegenheid van het beroep in de desbetreffende sectoren, zoals dit in het getallenvoorbeeld is weergegeven in schema 3.3. In tabel 3.4 is voor de sectoren chemie en metalektro de opdeling van de verwachte werkgelegenheidsontwikkeling naar sectoreffect en beroepseffect gepresenteerd ${ }^{9}$. Daarbij zijn deze effecten gerelateerd aan de totale werkgelegenheid van het beroep. Met deze manier van relateren wordt beter rekening gehouden met het relatieve belang van een sector voor het desbetreffende beroep. Een beroep kan binnen een sector immers sterk groeien, maar als deze sector voor dat beroep van minder belang is, is het uiteindelijke werkgelegenheidseffect hiervan voor het desbetreffende beroep toch vrij gering.

Tabel 3.4. Verwachte ontwikkeling van het aantal werkenden per beroepssegment in de sectoren chemie en metalektro, opgesplitst naar sectoreffect en beroepseffect 1993-1998 (gemiddelde jaarlijkse groei ten opzichte van de totale werkgelegenheid van het beroep)

\begin{tabular}{|c|c|c|c|c|c|}
\hline \multirow{2}{*}{$\begin{array}{l}\text { ROA- } \\
\text { code }\end{array}$} & \multirow[t]{2}{*}{ beroepssegment } & \multicolumn{2}{|c|}{ chemie } & \multicolumn{2}{|c|}{ metalektro } \\
\hline & & $\begin{array}{l}\text { SE } \\
\%\end{array}$ & $\begin{array}{l}\text { BE } \\
\%\end{array}$ & $\begin{array}{l}\text { SE } \\
\%\end{array}$ & $\begin{array}{l}\text { BE } \\
\%\end{array}$ \\
\hline
\end{tabular}

\begin{tabular}{|c|c|c|c|c|c|}
\hline $\begin{array}{l}301 \\
302\end{array}$ & $\begin{array}{l}\text { Lagere technische, ambachts- en industrieberoepen } \\
\text { Middelbare technische, ambachts- en industrieberoepen }\end{array}$ & $0, \overline{1}$ & $0, \overline{1}$ & $\begin{array}{l}-0,1 \\
-0,1\end{array}$ & $\begin{array}{r}-0,2 \\
0,0\end{array}$ \\
\hline 303 & Hogere technische, ambachts- en industrieberoepen & 0,1 & 0,2 & - & \\
\hline 311 & Lagere voedings- en genotmiddelenberoepen & - & - & - & \\
\hline 321 & Lagere textielberoepen & - & - & - & \\
\hline 331 & Lagere hout- en papierberoepen & - & - & $-0,0$ & $-0,0$ \\
\hline 341 & Lagere grafische beroepen & - & - & $-0,0$ & $-0,0$ \\
\hline 351 & Lagere chemische beroepen & 0,6 & $-1,3$ & - & \\
\hline 361 & Lagere metaalberoepen & 0,0 & 0,3 & $-0,3$ & $-0,4$ \\
\hline 362 & Middelbare metaalberoepen & - & - & $-0,0$ & $-0,1$ \\
\hline 363 & Hogere metaalberoepen & - & - & $-0,2$ & 0,9 \\
\hline 371 & Lagere elektrotechnische beroepen & - & - & $-0,3$ & $-0,5$ \\
\hline 372 & Middelbare elektrotechnische beroepen & - & - & $-0,1$ & 0,1 \\
\hline 373 & Hogere elektrotechnische beroepen & - & - & $-0,2$ & 1,8 \\
\hline 381 & Lagere bouwmaterialen-, glas- en aardewerkberoepen & 0,2 & $-1,5$ & $-0,1$ & 0,7 \\
\hline 391 & Lagere bouw- en installatieberoepen & - & - & $-0,0$ & 0,0 \\
\hline 392 & Middelbare bouw- en installatieberoepen & - & - & - & \\
\hline 393 & Hogere bouw- en installatieberoepen & - & - & - & \\
\hline
\end{tabular}

Bron: ROA

Als gevolg van de verwachte werkgelegenheidsgroei in de sector chemie is er voor alle beroepen in deze sector sprake van een positief sectoreffect: bij niet veranderende beroepenstructuur zou de werkgelegenheid voor elk beroep in deze sector iets stijgen. Omdat echter de chemische sector voor de meeste onderscheiden beroepen niet de belangrijkste sector is, blijft dit postieve werkgelegenheidseffect beperkt. Alleen voor de 'Lagere chemische

9. In bijlage $\mathrm{A}$ is een overzicht gegeven voor alle sectoren. 
beroepen' is de werkgelegenheid in de chemie doorslaggevend, blijkend uit een sectoreffect van $0,6 \%$. Belangrijker is echter dat dit beroepssegment binnen de chemische sector terrein verliest. De substitutie door andere beroepssegmenten in deze sector leidt tot een werkgelegenheidsverlies van $1,3 \%$ per jaar. Per saldo daalt de werkgelegenheid voor de 'Lagere chemische beroepen' als gevolg van de ontwikkelingen van en binnen de sector chemie derhalve met $0,7 \%$.

Voor de 'Lagere bouwmaterialen-, glas- en aardewerkberoepen' geldt een soortgelijk beeld. De geringe werkgelegenheidstoename die voor dit beroepssegment tot stand zou zijn gekomen door de positieve ontwikkeling van de chemische sector wordt ruimschoots teniet gedaan door de negatieve ontwikkeling van het beroep binnen de sector. Voor de andere onderscheiden beroepen binnen de sector chemie is het beeld positiever. Deze beroepen ontwikkelen zich iets gunstiger dan op grond van de sectorale ontwikkelingen mocht worden verwacht. Het effect van deze ontwikkelingen voor de totale werkgelegenheid voor de desbetreffende beroepssegmenten is met $0,2 \%$ tot $0,3 \%$ echter gering.

Voor de metalektro wordt voor de periode 1993-1998 een lichte afname van de werkgelegenheid verwacht. Bij gelijkblijvende beroepenstructuur in deze sector betekent dit derhalve dat werkgelegenheid als gevolg van dit sectoreffect in elk van de onderscheiden beroepssegmenten iets zou dalen. Dit effect is het sterkst voor de 'Lagere metaalberoepen' en de 'Lagere elektrotechnische beroepen', die in belangrijke mate van de metalektro afhankelijk zijn.

Binnen de metalektro is er een duidelijke verschuiving van de beroepenstructuur ten gunste van de 'Hogere elektrotechnische beroepen'. Vanwege dit beroepseffect is er sprake van een werkgelegenheidsstijging voor dit beroepssegment van maar liefst $1,8 \%$ gemiddeld per jaar. Daarmee is vrijwel de gehele verwachte werkgelegenheidsgroei van $2 \%$ voor dit beroepssegment verklaard. De tabel laat verder zien dat ook de 'Hogere metaalberoepen' en de 'Lagere bouwmaterialen-, glas- en aardewerkberoepen' zich binnen de metalektro gunstig ontwikkelen. De 'Lagere metaalberoepen' en de 'Lagere elektrotechnische beroepen' vertonen echter binnen de sector een ongunstige ontwikkeling. Dit betekent dat het toch al negatieve werkgelegenheidsperspectief voor deze beroepen als gevolg van de ontwikkeling van de werkgelegenheid in de metalektro nog eens extra onder druk staat.

\section{Beroepenfiches}

\section{Lagere technische, ambachts- en industrieberoepen}

In totaal zijn er ruim 50.000 werkenden met dit beroep. Daarbij is ongeveer $40 \%$ werkzaam als heftruck- of hefvorkchauffeur, terwijl $60 \%$ als machinist in de bouw of industrie werkzaam is. Het beroep is in een groot aantal sectoren vertegenwoordigd, waarbij de bouw met een werkgelegenheidsaandeel van ruim $20 \%$ de belangrijkste is. Voor de periode 1993-1998 wordt voor dit beroep een werkgelegenheidsstijging van $1 \%$ per jaar verwacht, die overigens vooral ten goede zal komen aan de heftruck- en hefvorkchauffeurs. Het beroep moet het daarbij met name hebben van een stijgend werkgelegenheidsaandeel in de sectoren 'Overige industrie' en 
'Handel'. In de metalektro is er naar verwachting een afname van de werkgelegenheid voor dit beroepssegment, niet alleen omdat de totale werkgelegenheid in deze sector iets afneemt, maar ook omdat binnen de metalektro de 'Lagere technische, ambachts- en industrieberoepen' aan belang verliezen.

\section{Middelbare technische, ambachts- en industrieberoepen}

Ongeveer 400.000 mensen zijn er in dit beroep werkzaam, waarvan het merendeel een leidinggevende functie in de produktie bekleedt. Ook allerlei andere leidinggevende functies worden echter tot dit beroepssegment gerekend. Dit maakt dat deze beroepsbeoefenaren in vrijwel alle bedrijfssectoren ruim zijn vertegenwoordigd. De belangrijkste daarvan zijn de 'Overige commerciële dienstverlening' (19\% van de werkgelegenheid), de metalektro (17\%) en de bouw (13\%). Op middellange termijn zal de werkgelegenheid voor dit beroep met circa 1,5\% per jaar stijgen. Vooral in de handel is er sprake van een forse werkgelegenheidsgroei die alleen al goed is voor een stijging van de werkgelegenheid voor dit beroep met $0,4 \%$. Dit komt overeen op een werkgelegenheidsstijging voor dit beroep binnen de sector met $5,5 \%$. Ook binnen de sector 'Overige commerciële dienstverlening' is er sprake van een sterke werkgelegenheidsgroei van dit beroep van maar liefst $0,9 \%$ per jaar: $0,2 \%$ vanwege de algehele werkgelegenheidstoename in deze sector er nog eens $0,7 \%$ omdat binnen de 'Overige commerciële dienstverlening' de 'Middelbare technische, ambachts- en industrieberoepen' een prominenter belang zullen krijgen. Tot slot wordt opgemerkt dat in de sector chemie de werkgelegenheid voor dit beroepssegment relatief sterk zal stijgen, terwijl er in de metalektro sprake is van een lichte afname van het aantal werkenden. De ontwikkelingen in beide sectoren zijn echter voor het beroep als geheel nauwelijks van belang.

\section{Hogere technische, ambachts- en industrieberoepen}

Dit beroep bevat ongeveer 40.000 personen die met name werkzaam zijn in de commerciële en niet-commerciële dienstverlening. Daarnaast werken er ongeveer 6.000 in de metalektro. Dit beroep mag tot de grootste groeiers op de arbeidsmarkt worden gerekend. Deze groei doet zich in vrijwel alle bedrijfssectoren voor. Bij de sector 'Openbaar bestuur, politie, defensie en onderwijs' ontkomt dit beroep echter niet aan de voor deze sector algehele werkgelegenheidsdaling. Binnen de sector krijgen de 'Hogere technische, ambachts- en industrieberoepen' weliswaar een iets hoger werkgelegenheidsaandeel, maar dit kan de algehele sectorale werkgelegenheidsdaling niet volledig compenseren. In de sector chemie is de werkgelegenheidsstijging van dit beroep iets groter dan het gemiddelde. Het beroep is in de metalektro nauwelijks vertegenwoordigd.

\section{Lagere voedings- en genotmiddelenberoepen}

Dit beroep met ruim 65.000 werkenden is sterk afhankelijk van de bedrijfssector 'Voedings- en genotmiddelenindustrie'. Ongeveer drie kwart van de arbeidskrachten is in deze sector werkzaam. Ook in de toekomst zal hierin weinig veranderen, zodat dit beroep deelt in de werkgelegenheidsmalaise die voor de 'Voedings- en genotmiddelenindustrie' wordt verwacht. In de chemie en de metalektro zijn nauwelijks arbeidskrachten met een lager voedings- en genotmiddelenberoep werkzaam. 


\section{Lagere textielberoepen}

In dit beroep zijn bijna 50.000 mensen werkzaam, waarvan ongeveer de helft een baan in de 'Overige industrie' heeft en dan met name in de onder deze sector vallende 'Kleding en schoenenindustrie'. De werkgelegenheid in deze sector neemt naar verwachting fors af, zodat ook voor de 'Lagere textielberoepen' het werkgelegenheidsperspectief ongunstig is. Als gevolg van de krimp in de sector neemt de werkgelegenheid in het beroep met ruim $0,5 \%$ af. Opvallend is echter dat binnen de 'Overige industrie' de 'Lagere textielberoepen' in belangrijke mate terrein verliezen, zozeer zelfs dat daardoor de werkgelegenheid voor dit beroep totaal gezien met meer dan $2 \%$ afneemt. De sectoren chemie en metalektro spelen voor dit beroep nauwelijks een rol van betekenis.

\section{Lagere hout- en papierberoepen}

Met ongeveer 130.000 werkenden mag dit beroep tot de grote technische beroepen worden gerekend. Daarbij kan worden opgemerkt dat meer dan $90 \%$ van de beroepsbeoefenaren tot de timmerlieden en andere houtbewerkers wordt gerekend, terwijl de rest houtwaren-, papier- of kartonmaker is. Het zal weinig verbazing wekken dat de bouw de belangrijkste bedrijfssector voor dit beroep is. In deze sector werken ongeveer 70.000 mensen met dit beroep. Ook in de 'Overige industrie' zijn echter vrij veel mensen, namelijk bijna 30.000, werkzaam. In de sectoren chemie en metalektro zijn er nauwelijks mensen die een lager hout- of papierberoep uitoefenen. Voor de komende jaren wordt voor dit beroep een lichte werkgelegenheidsdaling verwacht. Deze vindt met name plaats in de 'Overige industrie'. Niet alleen neemt hier de werkgelegenheid in de sector af, maar bovendien maakt het beroep binnen de sector een ongunstige ontwikkeling door. De lichte werkgelegenheidstoename die voor de bouw wordt verwacht, kan dit banenverlies niet compenseren.

\section{Lagere grafische beroepen}

Dit beroep telt ruim 50.000 arbeidskrachten, waarvan meer dan $70 \%$ werkzaam is in de 'Overige industrie'. Opvallend is dat dit beroep weet te ontkomen aan de algehele werkgelegenheidsdaling die in die sector optreedt. Binnen de sector maakt het beroep een erg gunstige ontwikkeling door: de werkgelegenheid voor de 'Lagere grafische beroepen' stijgt voor de 'Overige industrie' met bijna $4 \%$. De sectoren chemie en metalektro zijn ten slotte voor de 'Lagere grafische beroepen' niet of nauwelijks van belang.

\section{Lagere chemische beroepen}

De 'Lagere chemische beroepen' is met 28.000 werkenden een van de kleinere technische beroepssegmenten. Het merendeel van deze beroepsbeoefenaren is werkzaam in de sector chemie. In de metalektro zijn zij nauwelijks vertegenwoordigd. Ofschoon de chemische sector de komende jaren naar verwachting een lichte groei doormaakt, profiteren de 'Lagere chemische beroepen' daar niet van. Dit positieve werkgelegenheidseffect wordt namelijk meer dan volledig te niet gedaan door een voor dit beroep negatieve ontwikkeling van de beroepenstructuur binnen de sector. 


\section{Lagere metaalberoepen}

In totaal zijn er meer dan een kwart miljoen werkenden met dit beroep. Daarbij moet men onder meer denken aan lassers, machinebankwerkers, onderhoudsmonteurs enz. De metalektro is met een werkgelegenheidsaandeel van meer dan $60 \%$ de belangrijkste bedrijfssector voor dit beroep. Ook in de handel, de bouw en de 'Overige commerciële dienstverlening' is dit beroep nog redelijk vertegenwoordigd. Het werkgelegenheidsaandeel van de chemie is beperkt. De komende jaren zal de werkgelegenheid voor de 'Lagere metaalberoepen' ongeveer gelijk blijven. Wel zal er sprake zijn van opvallende verschuivingen in de sectorstructuur. Zo brokkelt de werkgelegenheid voor dit beroep in de sectoren metalektro en 'Overige industrie' af. Deze afname is groter dan op grond van de sectorale ontwikkelingen zou mogen worden verwacht. Binnen de chemie de handel en de 'Overige commerciële dienstverlening' gaan de 'Lagere metaalberoepen' daarentegen een iets sterkere positie innemen.

\section{Middelbare metaalberoepen}

De werkgelegenheid voor 'Middelbare metaalberoepen', zoals automonteurs en middelbare werktuigbouwkundigen, bedraagt momenteel ruim 60.000. Voor dit beroep is de 'Overige commerciële dienstverlening' de belangrijkste bedrijfssector. In deze sector is circa $45 \%$ van de beroepsbeoefenaren werkzaam. De handel heeft een werkgelegenheidsaandeel van bijna $15 \%$, terwijl in de metalektro ruim $10 \%$ van de arbeidskrachten werkzaam zijn. Het beroep komt in de chemie niet of nauwelijks voor. Voor dit beroep zal er de komende jaren sprake zijn van een ongeveer gelijkblijvende werkgelegenheid. Wel zal er een verschuiving in de werkgelegenheidsstructuur optreden: de metalektro neemt in belang af, terwijl de handel voor dit beroep belangrijker wordt. Dit hangt niet alleen samen met de ontwikkeling van deze twee sectoren, maar ook binnen de sectoren vindt er een verschuiving van de beroepenstructuur plaats. Hoewel de belangrijkste bedrijfssector voor dit beroep, de 'Overige commerciële dienstverlening', de komende jaren naar verwachting aanzienlijk zal groeien, kan het beroep daarvan niet profiteren. De werkgelegenheid voor de 'Middelbare metaalberoepen' neemt binnen de sector fors af.

\section{Hogere metaalberoepen}

Met 12.000 werkenden is het beroepssegment 'Hogere metaalberoepen' een van de kleinste. Voor dit beroep is de metalektro de belangrijkste bedrijfssector. De inkrimping van de werkgelegenheid die voor deze sector wordt verwacht, is derhalve voor de 'Hogere metaalberoepen' ongunstig. Binnen de metalektro is de werkgelegenheidsontwikkeling voor dit beroep echter dermate gunstig dat er per saldo sprake is van een redelijke toename van de werkgelegenheid. Totaal gezien zal in de periode 1993-1998 de werkgelegenheid voor dit beroep met ruim $0,5 \%$ per jaar stijgen.

\section{Lagere elektrotechnische beroepen}

In de 'Lagere elektrotechnische beroepen' zijn ongeveer 25.000 mensen werkzaam. Ruim de helft daarvan heeft een baan in de metalektro. Dit maakt de beroepsbeoefenaren sterk afhankelijk van deze sector. De teruggang van de werkgelegenheid die voor de sector wordt verwacht, werkt daarom sterk door in de werkgelegenheid van het beroep. Alleen al door dit 
sectoreffect zal de werkgelegenheid voor de 'Lagere elektrotechnische beroepen' met 0,3\% afnemen. Door een afnemend aandeel van het beroep binnen de sector staat de werkgelegenheid nog verder onder druk. Hierdoor daalt de werkgelegenheid met nog eens ongeveer $0,5 \%$. In de andere sectoren blijkt de werkgelegenheid voor de lagere elektrotechnici ongeveer gelijk. Totaal gezien treedt er voor dit beroep derhalve een werkgelegenheidsdaling op. Deze daling is naar verwachting ongeveer $0,7 \%$ per jaar.

\section{Middelbare elektrotechnische beroepen}

De 'Middelbare elektrotechnische beroepen' (bv. elektriciëns en elektromonteurs) vertegenwoordigen ruim 110.000 werkenden. De metalektro en de bouw zijn met elk 30.000 werkenden de belangrijkste bedrijfssectoren. In de handel zijn ongeveer 12.000 middelbare elektrotechnici werkzaam. De sector chemie is voor dit beroep echter nauwelijks van belang. Voor de periode 1993-1998 wordt voor dit beroep een min of meer stabiele werkgelegenheid verwacht. De werkgelegenheid voor dit beroep binnen de diverse onderscheiden bedrijfssectoren volgt vrij nauwkeurig de totale werkgelegenheidsontwikkeling binnen de desbetreffende sectoren. $\mathrm{Er}$ is met andere woorden nauwelijks sprake van een beroepseffect als gevolg van een sterk toenemend of afnemend werkgelegenheidsaandeel van de middelbare elektrotechnici binnen een sector.

\section{Hogere elektrotechnische beroepen}

In dit beroep zijn slechts 11.000 mensen werkzaam. Vanwege dit kleine aantal is er weinig bekend over de sectorstructuur van deze werkgelegenheid. Wel blijkt dat zo'n $40 \%$ van de werkenden een baan in de metalektro heeft. Binnen deze sector wordt voor de hogere elektrotechnici, tegen de algehele ontwikkeling van de sector in, een relatief sterke werkgelegenheidsgroei verwacht. In totaal zullen er de komende vijf jaar ongeveer 2.000 arbeidsplaatsen voor de 'Hogere elektrotechnische beroepen' bijkomen, overeenkomend met een jaarlijkse werkgelegenheidsgroei van circa $2 \%$.

\section{Lagere bouwmaterialen-, glas- en aardewerkberoepen}

Voor de 'Lagere bouwmaterialen-, glas- en aardewerkberoepen' is de sector chemie het belangrijkste. Ongeveer $30 \%$ van de 37.000 werkenden met dit beroep heeft een baan in chemische industrie. Verder is in elk van de sectoren metalektro en 'Overige industrie' circa $20 \%$ van de arbeidskrachten werkzaam. Voor de nabije toekomst wordt voor dit beroep een sterke afname van de werkgelegenheid verwacht. Deels is dit een sectoreffect. De werkgelegenheidsverwachtingen voor de metalektro en de 'Overige industrie' zijn immers niet gunstig. Voor de sector chemie als geheel wordt daarentegen een stijging van de werkgelegenheid verwacht. Binnen deze sector neemt het aandeel van de 'Lagere bouwmaterialen-, glas- en aardewerkberoepen' echter fors af. Ook binnen de 'Overige industrie' kan dit beroep het werkgelegenheidsaandeel niet vasthouden. In de metalektro is er echter sprake van een toename van de werkgelegenheid voor dit beroep. 


\section{Lagere bouw- en installatieberoepen}

In dit beroep zijn momenteel ongeveer 370.000 mensen werkzaam. Daarbij moet men denken aan metselaars, straatmakers, schilders, loodgieters enz. Van deze arbeidskrachten heeft ongeveer $40 \%$ een baan in de bouw. Andere belangrijke bedrijfssectoren voor dit beroep zijn de metalektro, de handel, de 'Overige commerciële dienstverlening', de 'Kwartaire diensten' en de sector 'Openbaar bestuur', politie, defensie en onderwijs'. Het werkgelegenheidsaandeel van deze sectoren loopt uiteen van $5 \%$ tot $10 \%$. In de chemische industrie zijn er nauwelijks arbeidskrachten die een lager bouw- of installatieberoep uitoefenen. Voor de periode 1993-1998 wordt voor dit beroep een lichte stijging van de werkgelegenheid verwacht. Deze toename wordt echter niet veroorzaakt door de verwachte werkgelegenheidsgroei in de bouwsectoren. De groei die in deze sector optreedt wordt vrijwel volledig gecompenseerd door een afname van het aandeel van de lagere bouwberoepen in die sector. De werkgelegenheidsgroei voor dit beroep hangt vooral samen met een lichte groei van de werkgelegenheid in de andere sectoren waarin men is vertegenwoordigd. Het beroep boekt nauwelijks werkgelegenheidswinst door een toenemend aandeel in bepaalde sectoren.

\section{Middelbare bouw- en installatieberoepen}

De 'Middelbare bouw- en installatieberoepen' (onder meer opzichters e.d.) vertegenwoordigen circa 30.000 werkenden. Deze zijn met name geconcentreerd in de sectoren bouw, 'Overige commerciële dienstverlening' en 'Openbaar bestuur, politie, defensie en onderwijs'. In de chemie en de metalektro zijn zij niet of nauwelijks vertegenwoordigd. Naar verwachting zal de werkgelegenheid voor dit beroep de komende jaren ongeveer gelijk blijven. Het beroep profiteert iets van de groei van de bouwsector, maar levert werkgelegenheid in bij de overheidssector.

\section{Hogere bouw- en installatieberoepen}

Dit beroep, waarbij men vooral moet denken aan architecten e.d., bestaat uit circa 28.000 werkenden. Daarvan is ongeveer de helft werkzaam in de 'Overige commerciële dienstverlening'. Daarnaast heeft ongeveer $20 \%$ een baan in de sector 'Openbaar bestuur, politie, defensie en onderwijs'. In de sectoren chemie en metalektro zijn er nauwelijks mensen in dit beroep werkzaam. De werkgelegenheidsverwachtingen voor dit beroep zijn gunstig. Dit is vooral te danken aan de 'Overige commerciële dienstverlening'. Niet alleen neemt de werkgelegenheid in deze sector als geheel toe, ook binnen de sector is er sprake van een aanzienlijke werkgelegenheidstoename voor de 'Hogere bouw- en installatieberoepen'. 


\section{OPLEIDINGENSTRUCTUUR PER BEROEP}

In deze paragraaf wordt de in paragraaf 3 beschreven beroepenstructuur en de verwachte ontwikkelingen daarin verbijzonderd naar de zeven in het ROA-informatiesysteem onderwijsarbeidsmarkt onderscheiden opleidingstypen. Eerst wordt aangegeven hoe groot de werkgelegenheid voor deze opleidingstypen momenteel is. Daarbij wordt tevens een verbijzondering naar enkele onderliggende opleidingen gemaakt. Voorts wordt aangegeven hoe deze opleidingen in de verschillende technische beroepen zijn vertegenwoordigd. Tot slot van deze paragraaf komt de voor de periode 1993-1998 verwachte werkgelegenheidsontwikkeling voor de desbetreffende opleidingstypen aan de orde. Deze ontwikkeling wordt tevens vergeleken met de werkgelegenheidsperspectieven van de onderscheiden technische beroepen.

\section{Opleidingenstructuur}

Tabel 4.1 geeft een overzicht van het aantal werkenden in de zeven in het informatiesysteem onderscheiden technische opleidingstypen. In de tabel is tevens een verbijzondering naar enkele onderliggende opleidingsrichtingen aangebracht (zie ook Willems, 1993). In totaal hebben ruim 1,4 miljoen werkenden een technische opleidingsachtergrond. Dit betreft ongeveer een kwart van de totale werkzame beroepsbevolking. Maar liefst $83 \%$ van alle werkende technische opgeleiden heeft een opleiding op VBO- of MBO-niveau gevolgd. Ruim $10 \%$ heeft een HBOopleiding afgesloten, terwijl ongeveer $7 \%$ met succes een academische studie heeft afgerond.

Tabel 4.1. Aantal werkenden per opleidingstype 1992

VBO technisch

498.000

w.v. bouwtechniek

137.000

installatietechniek

10.000

metaalkunde

140.000

werktuigbouwkunde

6.000

motorvoertuigentechniek

47.000

elektrotechniek

64.000

grafische techniek

10.000

consumptieve techniek

29.000

overig

56.000

MBO technisch laboratorium

MBO technisch

692.000

w.v. bouwkunde

145.000

weg-en waterbouwkunde

22.000

metaalkunde

63.000

fijnmechanische techniek

14.000

werktuigbouwkunde

89.000

motorvoertuigentechniek

62.000

elektrotechniek

148.000

procestechniek

17.000

overig

132.000 
Tabel 4.1. Aantal werkenden per opleidingstype 1992 (vervolg)

Opleidingstype

HBO technisch laboratorium

HBO technisch

123.000

w.v. bouwkunde

33.000

werktuigbouwkunde

31.000

elektrotechniek

40.000

overig

19.000

WO wis- en natuurkunde

38.000

WO technisch

54.000

19.000

w.v. bouwkunde

9.000

werktuigbouwkunde

9.000

techniek

18.000

overig

1.443 .000

Totaal technische opleidingen

Bron: CBS/ROA

Binnen de technische opleidingen zijn de richtingen bouwkunde en elektrotechniek het grootst. Respectievelijk ruim 330.000 en ruim 250.000 werkenden hebben een opleiding in deze richting afgerond. Op VBO- en MBO-niveau is verder de richting metaalkunde met ruim 200.000 werkenden vrij groot. Ook heeft een belangrijk deel van de arbeidskrachten een VBO- of MBOopleiding motorvoertuigentechniek gevolgd.

\section{Opleidingenstructuur per beroep}

Er is geen één-op-één-relatie tussen het werken in een technisch beroep en het hebben van een technische opleidingsachtergrond. Technisch opgeleiden kunnen een niet-technisch beroep uitoefenen, terwijl aan de andere kant niet-technisch opgeleiden juist wel in de technische richting werkzaam zijn. Dit laatste blijkt al uit het feit dat er ruim 300.000 meer technische beroepsbeoefenaren dan (werkende) technisch opgeleiden zijn. In tabel 4.2 is de verdeling van de technisch opgeleiden over de onderscheiden beroepen gepresenteerd. De belangrijkste niettechnische opleidingen binnen de technische beroepen zijn MBO economisch-administratief en HBO economisch-administratief. Daarnaast zijn er vooral ook relatief veel 'ongeschoolden' (uitsluitend basisonderwijs) in de technische beroepen werkzaam. 
Tabel 4.2. Aantal werkenden per beroepssegment en opleidingstype 1992

\begin{tabular}{llrrr}
\hline $\begin{array}{l}\text { ROA- } \\
\text { code }\end{array}$ & beroepssegment & $\begin{array}{r}\text { VBO } \\
\text { technisch }\end{array}$ & $\begin{array}{r}\text { MBO techn. } \\
\text { laboratorium }\end{array}$ & $\begin{array}{r}\text { MBO } \\
\text { technisch }\end{array}$ \\
\hline 301 & Lagere technische, ambachts- en industrieberoepen & 12.000 & - & 9.000 \\
302 & Middelbare technische, ambachts- en industrieberoepen & 32.000 & 5.000 & 112.000 \\
303 & Hogere technische, ambachts- en industrieberoepen & - & - \\
311 & Lagere voedings- en genotmiddelenberoepen & 14.000 & - & 18.000 \\
321 & Lagere textielberoepen & 9.000 & - & 8.000 \\
331 & Lagere hout- en papierberoepen & 47.000 & - & 45.000 \\
341 & Lagere grafische beroepen & 9.000 & - & 23.000 \\
351 & Lagere chemische beroepen & - & 11.000 \\
361 & Lagere metaalberoepen & 79.000 & - & 96.000 \\
362 & Middelbare metaalberoepen & 11.000 & - & 29.000 \\
363 & Hogere metaalberoepen & - & - \\
371 & Lagere elektrotechnische beroepen & 5.000 & - & - \\
372 & Middelbare elektrotechnische beroepen & 22.000 & - & 63.000 \\
373 & Hogere elektrotechnische beroepen & - & - \\
381 & Lagere bouwmaterialen-, glas- en aardewerkberoepen & 11.000 & - & 6.000 \\
391 & Lagere bouw- en installatieberoepen & 75.000 & - & 59.000 \\
392 & Middelbare bouw- en installatieberoepen & - & - & 16.000 \\
393 & Hogere bouw- en installatieberoepen & - & - & 5.000 \\
& & & &
\end{tabular}

301 Lagere technische, ambachts- en industrieberoepen

302 Middelbare technische, ambachts- en industrieberoep

303 Hogere technische, ambachts- en industrieberoepen

10.000

Lagere voedings- en ge

321 Lagere textielberoepen

331 Lagere hout- en papierberoepen

341 Lagere grafische beroepen

351 Lagere chemische beroepen

361 Lagere metaalberoepen

362 Middelbare metaalberoepen

363 Hogere metaalberoepen

371 Lagere elektrotechnische beroepen

372 Middelbare elektrotechnische beroepen

373 Hogere elektrotechnische beroepen

381 Lagere bouwmaterialen-, glas- en aardewerkberoepen

391 Lagere bouw- en installatieberoepen

392 Middelbare bouw- en installatieberoepen

393 Hogere bouw- en installatieberoepen

natuurkunde

- = minder dan 5.000 werkenden

Bron: CBS/ROA

Voor degenen die een technische opleiding op VBO-niveau hebben gevolgd, zijn de beroepssegmenten 'Lagere metaalberoepen' en 'Lagere bouw- en installatieberoepen' het belangrijkste. Gezien de verdeling naar opleidingsrichting binnen dit opleidingstype, als gepresenteerd in tabel 4.1, is dit niet verrassend. Daarmee zijn deze opleidingscategorieën ook sterk afhankelijk van de sectoren bouw en metalektro. Verder is een groot deel van de arbeidskrachten werkzaam in de 'Lagere hout- en papierberoepen'. Voor het opleidingstype MBO technisch laboratorium kan slechts worden gesteld dat circa $50 \%$ werkzaam is in de 
'Middelbare technische, ambachts- en industrieberoepen'. Voor het MBO technisch is dit eveneens het belangrijkste beroepssegment. Verder blijkt dat voor dit laatste opleidingstype de 'Lagere metaalberoepen' en in iets mindere mate de 'Lagere bouw- en installatieberoepen' erg belangrijk zijn. Daarnaast oefent een relatief groot deel van de werkenden een middelbaar elektrotechnisch beroep uit.

De werkgelegenheid voor hoger technisch opgeleiden kan op grond van deze cijfers niet goed worden verbijzonderd naar beroepssegment ${ }^{10}$. Een relatief groot deel van hen blijkt een middelbaar of hoger technisch ambachts- of industrieberoep uit te oefenen. Zoals echter al in paragraaf 3 is opgemerkt, betreft dit zeer heterogene categorieën. Voor het HBO technisch zijn verder de elektrotechnische en de bouw- en installatieberoepen relevant. Samen vertegenwoordigen deze beroepen ongeveer $20 \%$ van de werkgelegenheid voor technici op HBO-niveau.

Verwachte ontwikkeling in de opleidingenstructuur per beroep

Voor het transformeren van de verwachte ontwikkeling van de werkgelegenheid per beroep naar de onderscheiden opleidingstypen heeft het ROA het opleidingenmodel ontwikkeld (zie Borghans en Heijke, 1993). In dit model wordt de ontwikkeling van de opleidingenstructuur binnen de beroepssegmenten verklaard uit structurele effecten en de geschatte tendensen in de vraag naar een bepaald opleidingsniveau. Bovendien houdt het model rekening met substitutie-effecten als gevolg van veranderende vraag-aanbod-verhoudingen. Tabel 4.3 geeft een overzicht van de verwachte vraagontwikkeling voor de technische opleidingen in de periode 1993-1998.

Tabel 4.3. Verwachte ontwikkeling van de vraag per opleidingstype 1993-1998 (gemiddelde jaarlijkse groei)

\begin{tabular}{lr} 
Opleidingstype & $\%$ \\
\hline & \\
VBO technisch & $-0,5$ \\
MBO technisch laboratorium & 1,1 \\
MBO technisch & 1,0 \\
HBO technisch laboratorium & 2,5 \\
HBO technisch & 2,5 \\
WO wis- en natuurkunde & 2,7 \\
WO technisch & 3,6
\end{tabular}

Bron: ROA

De tabel laat duidelijk zien dat de werkgelegenheidsperspectieven beter zijn naarmate het

10. Voor het schatten en doorrekenen van modellen kan het ROA beschikken over data, waarbij een ondergrens van 2.500 in plaats van 5.000 werkenden wordt gehanteerd. Voor de verbijzondering van de huidige arbeidsmarktprognoses naar opleidingsrichting wordt bovendien gebruik gemaakt van additionele databestanden (zie Willems, 1993). 
opleidingsniveau hoger is. Voor de technisch opgeleiden op VBO-niveau wordt een lichte daling van de werkgelegenheid verwacht. De vraag naar technici op MBO-niveau neemt de komende jaren naar verwachting iets toe. De verwachte vraagstijging bedraagt hier circa $1 \%$ per jaar, hetgeen iets meer is dan de algehele werkgelegenheidsstijging van $0,7 \%$ per jaar in deze periode.

De werkgelegenheid voor hoger technisch opgeleiden zal zich de komende vijf jaar gunstig ontwikkelen. Voor technisch geschoolden op HBO-niveau zal het aantal arbeidsplaatsen met gemiddeld $2,5 \%$ per jaar stijgen. Voor wetenschappelijk opgeleide technici is de verwachte uitbreidingsvraag zelfs nog groter. Bij het opleidingstype WO wis- en natuurkunde bedraagt de vraagstijging naar verwachting $2,7 \%$ per jaar, terwijl voor WO technisch de verwachte toename van de vraag maar liefst $3,5 \%$ is.

Naar analogie met het in de vorige paragraaf gemaakte onderscheid tussen sectoreffect en beroepseffect, kan ten aanzien van de vraagontwikkeling voor een bepaald opleidingstype een decompositie naar beroepseffect en opleidingseffect worden gemaakt. Het beroepseffect geeft hierbij aan welk deel van de toe- of afname van de werkgelegenheid voor een bepaald opleidingstype enkel het gevolg is van de vraagontwikkeling in het desbetreffende beroepssegment. Het opleidingseffect of substitutie-effect staat voor de additionele vraagontwikkeling, die wordt veroorzaakt door veranderingen in de opleidingenstructuur voor het desbetreffende beroep.

Tabel 4.4 geeft voor de onderscheiden technische opleidingen een overzicht van de beroeps- en opleidingseffecten, verbijzonderd naar beroepssegment. In de tabel zijn alleen de technische beroepen opgenomen die relevant zijn voor de sectoren chemie en metalektro, i.c. tenminste 5.000 werkenden in deze sectoren hebben. De beroeps- en sectoreffecten zijn gepercenteerd ten opzichte van de werkgelegenheid van de desbetreffende opleiding in het beroep en niet, naar analogie met paragraaf 3, ten opzichte van de totale werkgelegenheid voor dat opleidingstype. Dit is gedaan omdat anders door het grote aantal onderscheiden beroepssegmenten de individuele effecten erg klein zouden worden, waardoor een onderlinge vergelijking vrijwel niet mogelijk is. Opgemerkt moet worden dat door deze wijze van percentering de relatieve beroepseffecten voor alle opleidingen binnen een beroep even groot zijn (vergelijk het sectoreffect in schema 3.3).

Voor het VBO techniek is er per saldo sprake van een negatief substitutie-effect. Terwijl de werkgelegenheid voor de technische beroepen waarin zij zijn vertegenwoordigd ongeveer gelijk blijft, is er sprake van een werkgelegenheidsdaling als gevolg van een veranderende opleidingenstructuur van $0,4 \%$ per jaar. Deze daling doet zich vooral voor bij de 'Middelbare technische ambachts- en industrieberoepen', waar het VBO technisch fors aan werkgelegenheidsaandeel verliest. Ook in de met name in de metalektro vertegenwoordigde beroepen 'Middelbare metaalberoepen' en 'Middelbare elektrotechnische beroepen' neemt de werkgelegenheid af, vanwege verschuivingen in de opleidingenstructuur binnen deze beroepen. 
Het opleidingstype MBO technisch laboratorium heeft eveneens te kampen met een (gering) negatief substitutie-effect. Voor de opgeleiden van het MBO technisch geldt daarentegen dat zij per saldo licht profiteren van de veranderingen in de opleidingenstructuur. In vrijwel alle relevante beroepen weet dit opleidingstype het werkgelegenheidsaandeel te versterken. Vooral binnen enkele lagere technische beroepen neemt het aandeel van MBO-opgeleiden sterk toe. Voor de 'Lagere technische, ambachts- en industrieberoepen', 'Lagere bouwmaterialen-, glasen aardewerkberoepen' en de 'Lagere bouw- en installatieberoepen' is het opleidingseffect zelfs $1,5 \%$ of meer. Alleen bij de 'Middelbare technische ambachts- en industrieberoepen' verliest het MBO technisch enigszins terrein ten opzichte van de andere opleidingen.

Tabel 4.4. Verwachte ontwikkeling van het aantal werkenden per opleidingstype in de voor de sectoren chemie en metalektro meest relevante technische beroepssegmenten, opgesplitst naar beroepseffect (BE) en opleidingseffect (OE) 1993-1998 (gemiddelde jaarlijkse groei ten opzichte van de werkgelegenheid van de opleiding in het beroep)

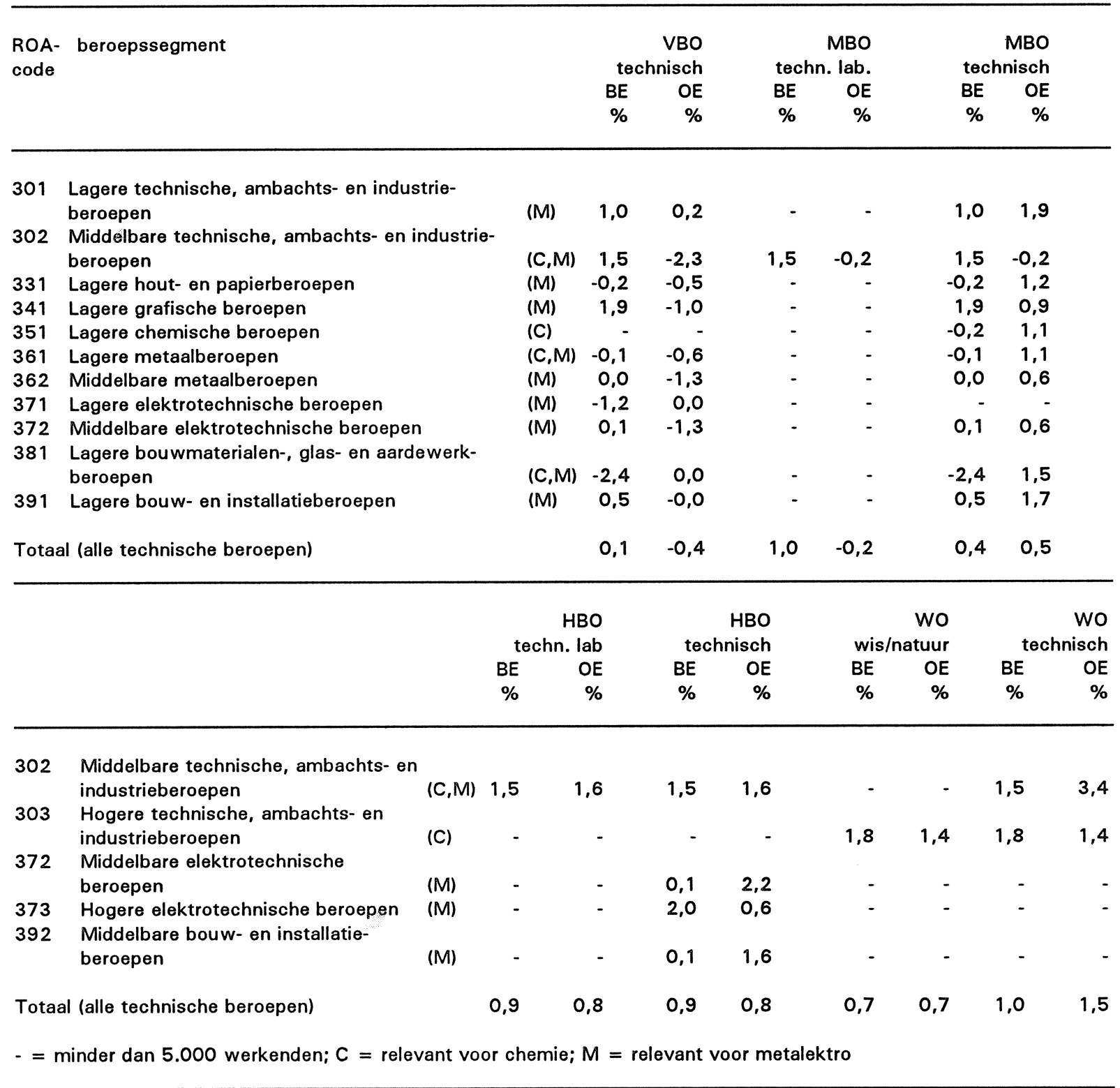


De verwachte ontwikkelingen voor de hogere technische opleidingen zijn zonder meer gunstig. Niet alleen is er sprake van een toenemende werkgelegenheid voor de beroepen, waarin zij vooral zijn vertegenwoordigd, maar bovendien nemen zij binnen deze beroepen een groter deel van de werkgelegenheid in. De tabel laat zien dat het opleidingstype HBO technisch vooral profiteert van de gunstige werkgelegenheidsperspectieven voor de 'Hogere elektrotechnische beroepen'. Binnen dit beroep neemt het aandeel van HBO technisch echter slechts weinig toe. Binnen de beroepssegmenten 'Middelbare technische, ambachts- en industrieberoepen', 'Middelbare bouw- en installatieberoepen' en vooral de 'Middelbare elektrotechnische beroepen' zal er daarentegen naar verwachting sprake zijn van een sterk toenemend aantal werkenden met een technische opleidingsachtergrond op HBO-niveau.

De algemene conclusie bij de tabel kan luiden dat er de komende jaren een verdergaande neerwaartse substitutie zal plaatsvinden. Vooral voor HBO- en WO-opgeleiden zal de werkgelegenheid toenemen deels als gevolg van een hoger gevraagd opleidingsniveau binnen de onderscheiden beroepen. Ook de MBO-opleidingen profiteren van de verschuivingen in de opleidingenstructuur, zij het in mindere mate. Het opleidingstype VBO technisch kampt als gevolg van deze ontwikkelingen met een dalende werkgelegenheid. 


\section{CONFRONTATIE VRAAG-AANBOD}

Voor het typeren van de toekomstige arbeidsmarktperspectieven voor de onderscheiden opleidingen is niet alleen de werkgelegenheidsontwikkeling relevant. Daarvoor is het tevens van belang om rekening te houden met de vervangingsvraag vanwege pensionering, VUT, arbeidsongeschiktheid e.d. en de verwachte instroom van nieuwkomers op de arbeidsmarkt ${ }^{11}$. In deze paragraaf zal achtereenvolgens op beide elementen worden ingegaan. Vervolgens wordt een indicatie van de toekomstige arbeidsmarktperspectieven van de verschillende technische opleidingen gegeven ${ }^{12}$. Tot slot wordt voor de zeven onderscheiden opleidingstypen in de technische richting een opleidingsfiche gepresenteerd.

\section{Vervangingsvraag}

De vervangingsvraag is dikwijls een belangrijker deel van de totale vraag naar nieuwkomers dan de uitbreidingsvraag (zie bijvoorbeeld De Grip en Willems, 1992). Tabel 5.1 geeft een overzicht van de voor de periode 1993-1998 verwachte vervangingsvraag voor de zeven onderscheiden technische opleidingen. Onmiddelijk blijkt dat de vervangingsvraag veel minder varieert dan de werkgelegenheidsontwikkeling. Daarmee gaat van de vervangingsvraag een stabiliserende werking uit op de totale vaag naar nieuwkomers ${ }^{13}$.

Tabel 5.1. Verwachte vervangingsvraag per opleidingstype 1993-1998 (gemiddeld jaarlijks percentage)

Opleidingstype $\quad \%$

$\begin{array}{lr}\text { VBO technisch } & 2,7 \\ \text { MBO technisch laboratorium } & 2,9 \\ \text { MBO technisch } & 2,4 \\ \text { HBO technisch laboratorium } & 1,8 \\ \text { HBO technisch } & 3,1 \\ \text { WO wis- en natuurkunde } & 2,7 \\ \text { WO technisch } & 2,9 \\ & 2,8 \\ \text { Totaal (alle opleidingstypen) } & \end{array}$

Bron: ROA

De gemiddelde vervangingsvraag over alle opleidingstypen, dus ook de niet-technische, bedraagt $2,8 \%$ per jaar. Voor vrijwel alle technische opleidingen is de vervangingsvraag

11. Zie voor een verdere toelichting Dekker, De Grip, Borghans, Matheeuwsen, Wieling en Willems (1993).

12. De resultaten van de vervangingsvraag, de instroom van schoolverlaters en de arbeidsmarktprespectieven zijn eerder gepresenteerd in de Statistische bijlage bij De arbeidsmarkt naar opleiding en beroep tot 1998 (ROA, 1993b).

13. Deze totale vraag, zijnde de som van uitbreidings- en vervangingsvraag, wordt ook wel aangeduid als het totaal aantal baanopeningen (zie ROA, 1993a). 
ongeveer gelijk aan dit gemiddelde. Een uitzondering wordt daarbij gevormd door de HBOopleidingen. Voor het opleidingstype HBO technisch laboratorium is de toekomstige vervangingsvraag naar verwachting aanzienlijk lager. Voor het $\mathrm{HBO}$ technisch wordt daarentegen een iets hoger dan gemiddelde vervangingsvraag verwacht.

\section{Instroom van schoolverlaters}

Tegenover het totaal aantal baanopeningen staat het aanbod van nieuwkomers op de arbeidsmarkt. Daarbij kan een onderscheid worden gemaakt tussen het aanbod van het 'nog boven de markt zwevende' aanbod van werklozen aan het begin van de prognoseperiode en de instroom van schoolverlaters gedurende deze gehele periode. Een overzicht van de verwachte instroom van schoolverlaters per opleidingstype is gepresenteerd in tabel 5.2. Daarbij is aangegeven hoe groot deze instroom gemiddeld is ten opzichte van de werkgelegenheid.

Tabel 5.2. Verwachte instroom van schoolverlaters per opleidingstype 1993-1998 (gemiddeld jaarlijks percentage)

Opleidingstype $\quad \%$

VBO technisch $\quad 2,3$

MBO technisch laboratorium $\quad 2,5$

$\begin{array}{ll}\text { MBO technisch } & 3,7\end{array}$

HBO technisch laboratorium $\quad 3,5$

HBO technisch $\quad 4,2$

WO wis- en natuurkunde $\quad 3,9$

$\begin{array}{ll}\text { WO technisch } & 6,0\end{array}$

Totaal (alle opleidingstypen) $\quad 3,4$

Bron: ROA

Gemiddeld over alle opleidingen bedraagt de verwachte instroom van schoolverlaters $3,4 \%$ per jaar. Bij het opleidingstype VBO technisch is deze instroom echter aanzienlijk lager, namelijk $2,3 \%$. Ook bij het MBO technisch laboratorium is er sprake van een lager dan gemiddelde arbeidsmarktinstroom van schoolverlaters. Vooral voor het hoger technisch onderwijs wordt ten opzichte van de huidige werkgelegenheid een relatief grote instroom van schoolverlaters op de arbeidsmarkt verwacht. Zo is de instroom bij WO technisch maar liefst $6,0 \%$ gemiddeld per jaar. Ook de arbeidsmarktinstroom bij het HBO technisch is met $4,2 \%$ duidelijk hoger dan het gemiddelde.

\section{Indicatie toekomstige arbeidsmarktperspectieven}

De confrontatie van de vraag met het aanbod bepaalt het arbeidsmarktperspectief van een opleidingstype. In tabel 5.3 staat aangegeven wat de middellange-termijn-arbeidsmarktperspectieven voor de technische opleidingen zijn. Het blijkt dat de perspectieven voor 
technisch opgeleiden op VBO- en MBO-niveau slechts matig zijn. Het opleidingstype MBO technisch laboratorium vormt hierop een uitzondering. De arbeidsmarktperspectieven voor dit opleidingstype zijn gunstig.

Tabel 5.3. Verwachte arbeidsmarktpositie per opleidingstype 1993-1998

$\begin{array}{ll}\text { Opleidingstype typering } & \text { type }\end{array}$

$\begin{array}{ll}\text { VBO technisch } & \text { matig } \\ \text { MBO technisch laboratorium } & \text { goed } \\ \text { MBO technisch } & \text { matig } \\ \text { HBO technisch laboratorium } & \text { goed } \\ \text { HBO technisch } & \text { goed } \\ \text { WO wis- en natuurkunde } & \text { goed } \\ \text { WO technisch } & \text { redelijk }\end{array}$

Bron: ROA

Ook de perspectieven voor de hoger technisch opgeleiden zijn de komende jaren gunstig. Dit hangt vooral samen met de erg positieve werkgelegenheidsontwikkeling die voor deze opleidingen wordt verwacht. Het opleidingstype wO technisch heeft redelijke arbeidsmarktperspectieven. Deze iets minder gunstige typering van de perspectieven op de arbeidsmarkt ten opzichte van de andere hogere technische opleidingen, wordt vooral veroorzaakt door de naar verwachting grote instroom van schoolverlaters op de arbeidsmarkt.

Een sterker aantrekkende economie dan waarvan momenteel in het behoedzame CPB-scenario wordt uitgegaan zal tot gevolg hebben dat de werkgelegenheid voor technisch opgeleiden verder toeneemt dan in dit werkdocument is aangegeven. De goede perspectieven voor hoger opgeleide technici zullen daardoor alleen maar verbeteren. Vanuit werkgeversstandpunt geredeneerd betekent dit dat de kans op knelpunten bij de recrutering van nieuwe arbeidskrachten groter zal worden. Voor MBO-opgeleiden zal het perspectief bij een aantrekkende economie ook iets beter worden. Het arbeidsmarktperspectief voor schoolverlaters van het VBO technisch blijft ook bij gunstiger economische ontwikkeling waarschijnlijk matig. Het is derhalve niet te verwachten dat voor VBO-opgeleiden in de technische richting tot 1998 ernstige recruteringsproblemen ontstaan.

\section{Opleidingsfiches}

\section{VBO technisch}

Bijna een half miljoen arbeidskrachten hebben een technische opleiding op VBO-niveau gevolgd. Daarbinnen zijn de richtingen bouwtechniek en metaalkunde het grootste. Dit betekent dat dit opleidingstype sterk vertegenwoordigd is in de 'Lagere hout- en papierberoepen' (timmerlieden), de 'Lagere metaalberoepen' en de 'Lagere bouw- en installatieberoepen'. Deze beroepssegmenten zijn sterk gerelateerd aan de bedrijfssectoren bouw en metalektro. Voor de komende 
jaren wordt voor het VBO technisch een lichte afname van de werkgelegenheid verwacht. Deze daling is vooral het gevolg van een substitutie door hoger opgeleiden. De werkgelegenheid voor de technische beroepen waarin de VBO-ers werkzaam zijn, blijft nagenoeg gelijk. De toekomstige vraag naar technisch opgeleiden op VBO-niveau moet komen van de vervanging van de huidige arbeidskrachten. Deze vervangingsvraag is ongeveer gelijk aan het gemiddelde. De verwachte arbeidsmarktinstroom van schoolverlaters is relatief laag, maar desondanks zijn de middellange-termijn arbeidsmarktperspectieven voor dit opleidingstype matig.

\section{MBO technisch laboratorium}

Het opleidingstype MBO technisch laboratorium is met 11.000 werkenden vrij klein. Van deze arbeidskrachten is bijna $50 \%$ werkzaam in het beroepssegment 'Middelbare technische ambachts- en industrieberoepen', dat zowel in de sector chemie als in de metalektro sterk is vertegenwoordigd. Het MBO technisch laboratorium is voor de toekomstige ontwikkeling van de werkgelegenheid sterk afhankelijk van de werkgelegenheidsperspectieven van het genoemde beroep. Daar deze werkgelegenheid zich gunstig ontwikkelt en het MBO technisch laboratorium het werkgelegenheidsaandeel binnen dit beroep vrijwel weet vast te houden, kan het technisch laboratoriumonderwijs op MBO-niveau een redelijke groei realiseren van ongeveer $1 \%$ per jaar. Samen met een gemiddelde vervangingsvraag en een relatief lage instroom van schoolverlaters op de arbeidsmarkt, betekent dit dat de middellange-termijn arbeidsmarktperspectieven voor dit opleidingstype gunstig zijn. Door de sterke afhankelijkheid van de 'Middelbare technische, ambachts- en industrieberoepen' kan men bij een onverwachte omslag van de werkgelegenheidsontwikkeling overigens wel moeilijk uitwijken naar andere beroepen.

\section{MBO technisch}

Bijna 700.000 werkenden in ons land hebben een technische opleidingsachtergrond op MBOniveau. Dit is ongeveer $12 \%$ van de totale werkzame beroepsbevolking. Binnen dit opleidingstype zijn de richtingen bouwkunde en elektrotechniek met respectievelijk 145.000 en 148.000 werkenden het grootst. Voor het MBO technisch zijn vooral de 'Middelbare technische ambachts- en industrieberoepen', de 'Lagere metaalberoepen', de 'Middelbare elektrotechnische beroepen' en de 'Lagere bouw- en installatieberoepen' van belang. Deze beroepen zijn alle sterk in de metalektro vertegenwoordigd, hetgeen het MBO technisch redelijk afhankelijk van deze sector maakt. Ondanks de negatieve werkgelegenheidsontwikkeling die voor de metalektro wordt verwacht, weet het MBO technisch een groei te realiseren van ongeveer $1 \%$ per jaar. Dit komt enerzijds omdat zij zijn vertegenwoordigd in een groot aantal beroepen, maar vooral ook omdat zij binnen de meeste technische beroepen een toenemend aandeel in de werkgelegenheid zullen krijgen, hetgeen vooral ten koste gaat van het VBO technisch. De toekomstige perspectieven op de arbeidsmarkt zijn desondanks slechts matig, hetgeen vooral samenhangt met een bovengemiddelde instroom van nieuwkomers op de arbeidsmarkt.

\section{HBO technisch laboratorium}

Ruim 25.000 werkenden hebben een opleiding HBO technisch laboratorium gevolgd. Van hen zijn er circa 10.000 werkzaam in het beroepssegment 'Middelbare technische, ambachts- en industrieberoepen'. Voor de komende jaren wordt voor deze opleiding een forse groei van de 
vraag van $2,5 \%$ gemiddeld per jaar verwacht. Dit komt zowel omdat zij zijn vertegenwoordigd in beroepen, waarvoor de werkgelegenheid zal toenemen als door een stijgend aandeel binnen deze beroepen. De vervangingsvraag is voor dit beroep relatief laag. Bij een arbeidsmarktinstroom die naar verwachting ongeveer gelijk aan het gemiddelde is, staat de hoge werkgelegenheidsgroei echter garant voor gunstige perspectieven voor de schoolverlaters van dit opleidingstype.

\section{HBO technisch}

Het opleidingstype HBO technisch is door ongeveer 125.000 werkenden in ons land gevolgd. Daarbij gaat het in ongeveer gelijke mate over afgestudeerden in de bouwkunde, de werktuigbouwkunde en de elektrotechniek. De middelbare en hogere bouw- en installatieberoepen en de middelbare en hogere elektrotechnische beroepen zijn voor dit opleidingstype erg belangrijk, ofschoon de werkenden met deze opleidingsachtergrond ook in vele andere beroepen zijn vertegenwoordigd. De hogere technische beroepen maken de komende jaren naar verwachting een grote groei door, terwijl er een toenemende vraag naar technisch opgeleiden op HBO-niveau binnen de middelbare technische beroepen is. Dit maakt, ondanks een bovengemiddelde instroom van schoolverlaters de arbeidsmarktperspectieven voor het opleidingstype $\mathrm{HBO}$ technisch erg gunstig.

WO wis- en natuurkunde

Bijna 40.000 werkenden hebben een universitaire opleiding in de wiskunde of natuurwetenschappen afgesloten. Van hen werken er zo'n 14.000 in het onderwijs. De beroepsmogelijkheden voor deze afgestudeerden zijn echter redelijk gevarieerd, zodat zij meeprofiteren van de algehele werkgelegenheidsgroei die voor de Nederlandse economie in de periode 1993-1998 wordt verwacht. Daarnaast zal er per saldo binnen de onderscheiden beroepen een toenemende vraag naar wiskundigen en natuurwetenschappers ontstaan. De totale werkgelegenheidsgroei voor dit opleidingstype bedraagt naar verwachting $2,7 \%$. Dit zorgt ervoor dat de middellangetermijn-arbeidsmarktperspectieven goed zijn.

\section{WO technisch}

Van de werkenden hebben er ruim 50.000 een technische achtergrond op WO-niveau. Ongeveer $35 \%$ daarvan is afgestudeerd in de richting bouwkunde of weg- en waterbouw. Het aantal arbeidsplaatsen voor WO technici zal de komende jaren fors toenemen: de uitbreidingsvraag bedraagt maar liefst 3,6\% per jaar. Een groot deel daarvan hangt samen met de substitutie van anders opgeleiden door personen met een opleiding WO technisch. Doordat echter voor de komende jaren een aanzienlijke instroom van pas afgestudeerden op de arbeidsmarkt wordt verwacht, zijn de arbeidsmarktperspectieven minder gunstig dan op grond van de werkgelegenheidsontwikkeling zou worden verwacht. De perspectieven kunnen als redelijk worden getypeerd. 


\section{BESLUIT}

In dit werkdocument is een beeld geschetst van de werkgelegenheidsstructuur van technische beroepsbeoefenaren en technisch opgeleiden. Naast de huidige structuur is tevens ingegaan op de verwachte ontwikkelingen hierin. Daarbij is speciale aandacht besteed aan de bedrijfssectoren chemie en metalektro.

In de sector chemie zal de werkgelegenheid iets toenemen. Deze groei komt echter niet ten goede aan de 'Lagere chemische beroepen', omdat binnen de chemische industrie dit beroep aan terrein verliest. Ook de 'Lagere bouwmaterialen-, glas- en aardewerkberoepen', die relatief sterk in de sector chemie zijn vertegenwoordigd, hebben binnen deze sector te kampen met een afbrokkelende werkgelegenheid.

De sector metalektro zal de komende jaren iets in werkgelegenheid teruggaan. Voor de meeste technische beroepen zal het aantal werkenden binnen deze sector daardoor eveneens iets dalen. Opvallende uitzonderingen zijn daarbij de 'Hogere metaalberoepen' en de 'Hogere elektrotechnische beroepen'. Dit beeld wijst op een toenemende complexiteit van de beroepsactiviteiten in Nederland.

Het beeld van complexere werkzaamheden wordt bevestigd door de verwachte ontwikkelingen van neerwaartse substitutie in de opleidingenstructuur. Voor technisch opgeleiden op VBOniveau wordt een afname van de vraag verwacht. Voor MBO-ers is er sprake van een geringe toename van het aantal arbeidsplaatsen, terwijl de vraag naar hoger opgeleide technici de komende jaren fors zal toenemen. Dit hangt niet alleen samen met de verwachte werkgelegenheidsgroei voor de hogere technische beroepen. Het is ook het gevolg van een toenemende vraag naar hoger opgeleide technici binnen de middelbare technische beroepen. Binnen de lagere technische beroepen zullen de MBO-opgeleiden een groter aandeel van de werkgelegenheid krijgen.

De arbeidsmarktperspectieven voor technici, bepaald door middel van de confrontatie van toekomstige vraag- en aanbodstromen, zijn vooral gunstig voor de hoger opgeleiden. Ook voor het opleidingstype MBO technisch laboratorium zijn de toekomstige perspectieven op de arbeidsmarkt goed. Voor de technische opleidingen op VBO-niveau en voor het opleidingstype MBO technisch wordt de toekomstige arbeidsmarktsituatie als matig getypeerd.

Een nadeel van de in dit werkdocument gepresenteerde arbeidsmarktprognoses voor technisch opgeleiden is dat deze slechts zijn verbijzonderd naar opleidingsniveau en niet naar de afzonderlinge opleidingen binnen de technische richting. Binnen een bepaald opleidingstype kan immers het beeld voor de diverse onderliggende opleidingen variëren. Het ROAinformatiesysteem verschaft echter op dit moment geen meer gedetailleerde informatie. Onlangs is echter een onderzoeksproject gestart om deze verbijzondering van de prognoses voor technisch opgeleiden wel te maken. Deze gedetailleerde prognoses zullen worden gecombineerd met een aantal actuele cijfers en indicatoren over de arbeidsmarkt voor technisch opgeleiden. 
$-31-$

Ook zal een link worden gelegd met de arbeidsmarktpositie van de schoolverlaters van het technisch onderwijs. De verslaglegging van dit onderzoek zal naar verwachting in het najaar van 1994 zijn afgerond. 


\section{LITERATUUR}

Borghans, L., H. Heijke (1993), Forecasting the Educational Structure of Occupations: $A$ Manpower Requirement Approach with Substitution, ROA-RM-1993/2E, Maastricht.

Borghans, L., H. Heijke (1994), Een random-coëfficiëntenmodel voor het voorspellen van de beroepenstructuur van bedrijfstakken, ROA-W-1994/1, Maastricht.

Centraal Bureau voor de Statistiek (1993), Enquête Beroepsbevolking 1992, Voorburg/Heerlen.

Centraal Planbureau (1993), Centraal Economisch Plan 1993, SDU-Uitgeverij, Den Haag.

Dekker, R.J.P., A. de Grip, L. Borghans, A.G.M. Matheeuwsen, M.H. Wieling, E.J.T.A. Willems (1993), Methodiek van het informatiesysteem onderwijs-arbeidsmarkt 1993, ROA-W-1993/3, Maastricht.

Grip, A. de, E.J.T.A. Willems (1992), De vervangingsvraag naar beroepsklasse tot 2000, OSAwerkdocument W96, Den Haag.

Loo, P.J.E. van de, R.J.P. Dekker, A. de Grip (1992), Arbeidsmarktsegmentatie als uitgangspunt voor een beroepenclassificatie, Tijdschrift voor Arbeidsvraagstukken, jrg. 8, nr. 1, blz. 19-31.

Researchcentrum voor Onderwijs en Arbeidsmarkt (1993a), De arbeidsmarkt naar opleiding en beroep tot 1998, ROA-R-1993/10, Maastricht.

Researchcentrum voor Onderwijs en Arbeidsmarkt (1993b), De arbeidsmarkt naar opleiding en beroep tot 1998. Statistische bijlage, ROA-R-1993/10B, Maastricht.

Willems, E.J.T.A. (1993), De arbeidsmarkt voor technisch opgeleiden: Haalbaarheidsonderzoek, ROA-R-1993/12, Maastricht. 


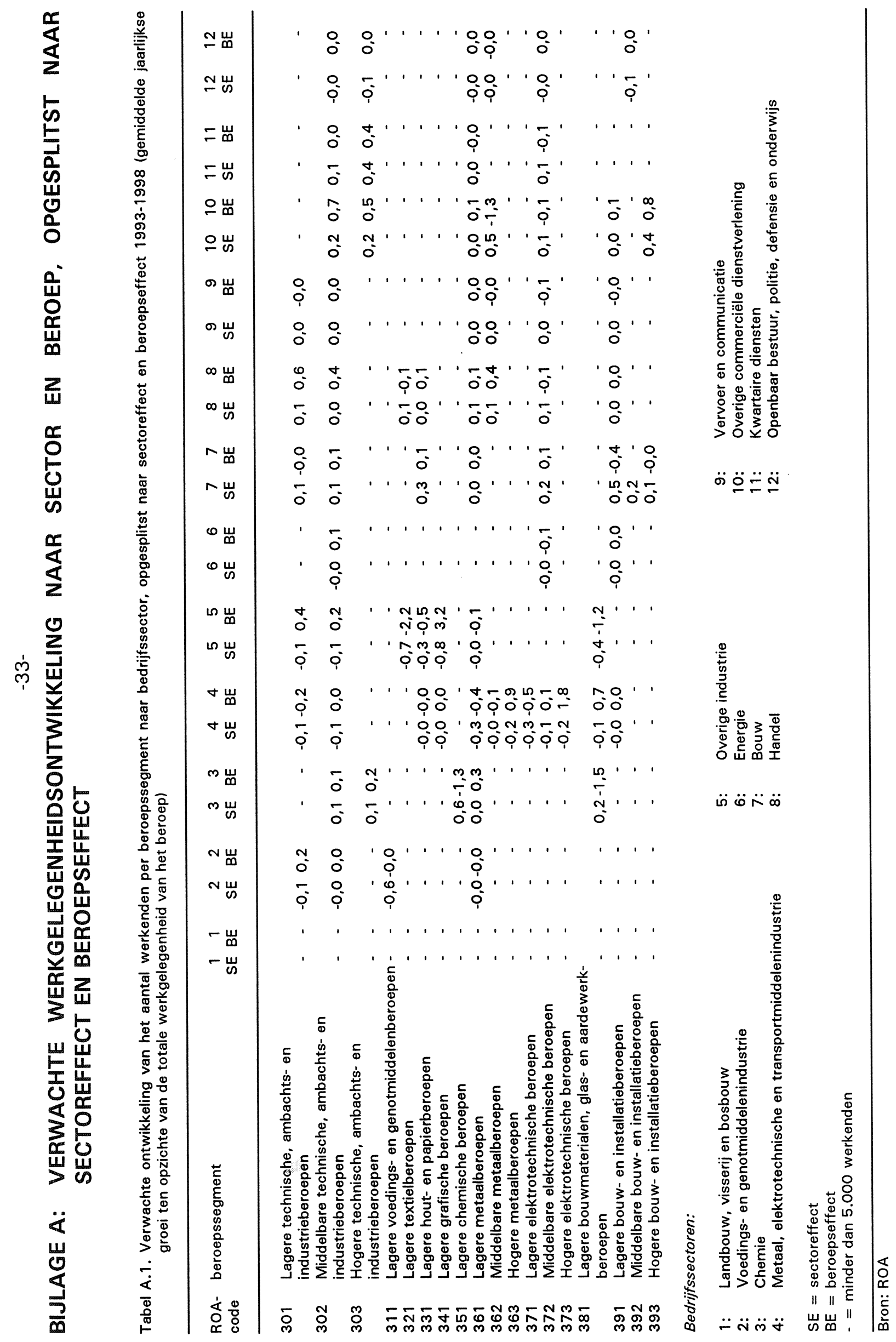

